\title{
OPTIMIZATION OF ADSORPTION OF PB (II) AND CR (VI) FROM AQUEOUS SOLUTION USING MODIFIED FELDSPAR COMPOSITE: ISOTHERM AND KINETIC STUDIES
}

\author{
Kabir Adebayo Sanusi ${ }^{1} \underset{(10}{ }$, Yakubu Yahaya ${ }^{2}$, Murtala M Ambrusa ${ }^{3}$, Aminu Koko Rabiu ${ }^{3}$ and \\ Abdulazeez M Hammed ${ }^{4}$ \\ ${ }^{1} \mathrm{PhD}$ Student, Department of Pure and Applied Chemistry, Kebbi State University of Science and Technology Aliero Kebbi \\ State, Nigeria \\ ${ }^{2}$ Associate Professor, Department of Pure and Applied Chemistry, Kebbi State University of Science and Technology Aliero \\ Kebbi State, Nigeria \\ ${ }^{3}$ Senior Lecturer, Department of Pure and Applied Chemistry, Kebbi State University of Science and Technology Aliero \\ Kebbi State, Nigeria \\ ${ }^{4}$ Research Fellow, Department of Chemistry, University of Ibadan Oyo State, Nigeria
}
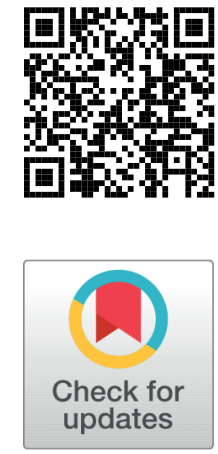

\section{ABSTRACT}

Received 3 June 2021

Accepted 18 June 2021

Published 12 July 2021

Corresponding Author

Kabir Adebayo Sanusi, adebayoka

bir@ymail.com

DOI $10.29121 /$

IJOEST.v5.i4.2021.200

Funding: This research received no specific grant from any funding agency in the public, commercial, or not-for-profit sectors.

Copyright: (C) 2021 The Author(s). This is an open access article distributed under the terms of the Creative Commons Attribution License, which permits unrestricted use, distribution, and reproduction in any medium, provided the original author and source are credited.
In this study modified feldspar composite (MFC) adsorbent based on feldspar and Theobroma cacao pods (TCP) was prepared, characterized and utilized for adsorption of $\mathrm{Pb}$ (II) and $\mathrm{Cr}$ (VI) in aqueous solution. The results showed that the cation exchange capacity of the modified feldspar composite $30.66 \pm$ $0.21 \mathrm{meq} / 100 \mathrm{~g})$ was 5 times higher than that of raw feldspar $(6.42 \pm 0.45$ meq/100g). More so, the novel biohybrid material, MFC has a surface area of $53.60 \pm 0.3 \mathrm{~m}^{2} / \mathrm{g}$ and particle size of $105.4 \pm 0.18$. X-ray diffraction peaks revealed that after the modification process, there is only slight shift in the position of some diffraction peaks of feldspar and the composite material suggestive of the retention of the crystalline properties of the feldspar in the novel composite (MFC). Infrared spectroscopy (FTIR) spectra showed that some functional groups present in the two starting materials were also available on the surface of the composite (MFC) indicating that the intercalation of TCP biomass into feldspar surface was successful. Response surface methodology (RSM) via a five-levels central composite design (CCD) was applied for optimization of metal adsorption onto the adsorbent in 32 experiment runs considering the effect of $\mathrm{pH}$, adsorbent dose, adsorbate concentration and contact time. Optimization results showed that the predicted and experimental values of $\mathrm{Pb}$ $(14.021,14.148 \mathrm{mg} / \mathrm{g})$ and $\operatorname{Cr}(3.428,3.504 \mathrm{mg} / \mathrm{g})$ were close at the optimum condition of ( $\mathrm{pH} \mathrm{2,} \mathrm{5,} \mathrm{6;} 0.5 \mathrm{~g} ; 100 \mathrm{mg} / \mathrm{L} ; 60-120 \mathrm{~min}$ and $\left.300^{0} \mathrm{~K}\right)$. Results of ANOVA analysis revealed the adequacy of the model with the good correlation between $\mathrm{R}^{2}$ values (0.9916-0.9998) and adjusted $\mathrm{R}^{2}$ (0.9919-0.9986) and $\mathrm{F}$ value of $(\geq 147)$. Results showed that $\mathrm{Pb}$ (II) ions adsorption onto the adsorbents was well fitted to the Langmuir isotherm model while the $\mathrm{Cr}$ (VI) 
ions uptake onto FS and MFC adsorbents followed Freundlich isotherm model. The results of the kinetic studies showed that rate of $\mathrm{Pb}$ (II) removal followed pseudo second order model while the rate of adsorption of $\mathrm{Cr}$ (VI) onto the FS and MFC adsorbents best fitted pseudo first order model. Owing to its improved cation exchange capacity and eco-friendliness, the modified feldspar composite have a good potential application in wastewater treatment besides other industrial explorations.

Keywords: Characterization, Composite, Feldspar, Calcination, FTIR, SEM, XRD

\section{INTRODUCTION}

The presence of heavy metals in water sources has become a significant topic of concern for scientists in various fields associated with quality of life of living things and health of the natural environment as well as concern of the general public Dang et al. (2009). Heavy metals are one of the most worrisome pollutants in the environment due to their potential toxicity, persistence and bio-accumulation problems. Direct toxicity to man and other forms of life and indirect toxicity through the food chains are the focus of this concern M. et al. (2003).

Lead (II) ion is widely used in many industries including painting, petrochemical, smelting, metal electroplating, mining, battery industries and plumbing. It is a cumulative poison that enters the body from water pipes made of lead, lead-based paints and leaded petrol Sanusi and Umar (2016). Presence of Pb(II) ions even at trace level in environment cause many fatal diseases including malfunctioning of renal blood and neurological systems, blood, kidney, reproductive system, nervous system and brain damage Karl (2004). The permissible level for $\mathrm{Pb}$ in drinking water is 0.01 mg/L Jimoh et al. (2011).

Chromium exists in stable form as Cr (III) ion and $\mathrm{Cr}$ (VI) ion, all other oxidation states of $\mathrm{Cr}$ are not stable in aqueous solutions. $\mathrm{Cr}$ (VI) is primarily present in the form of dichromate $\left(\mathrm{Cr}_{2} \mathrm{O}_{7}{ }^{2-}\right)$ and poses higher toxicity than the other oxidation states Saeed et al. (2005). Chromium-polluted water may be from dyeing industry, wood preservation, electroplating and leather tannery. Ingestion of $\mathrm{Cr}(\mathrm{VI})$ can result in ulcer and perforation of the mucous membranes of the nasal cavity, dermatitis, respiratory problems, kidney and liver damage (Khan et al., 2001).

Removal of toxic heavy metals by adsorption using low-cost adsorbents is a latest method of choice in the water treatment Dang et al. (2009). This is due to the several techno-economic advantages associated with low-cost adsorbents when compared to conventional water treatment techniques. Such techno-economic merits include low-cost, easy to obtain, process and utilize, available in abundance as wastes, good efficiency of adsorption and environmental friendly B. I. Olu-Owolabi et al. (2016).

Cocoa (Theobroma cacao) is an important agricultural and economic crop. It is one of the key economic crops cultivated in Nigeria. As the third largest producer of cocoa in Africa and one of the highest cocoa producer in the world, the produc- 
tion capacity of Nigeria was reported to have reached about 385,000 tonnes per annum B. Olu-Owolabi et al. (2012); Lateef et al., 2016). Cocoa beans are the primary economic part of the cocoa fruit and are the principal ingredients in the manufacture of chocolate and other derived products such as cocoa liquor, cocoa butter, cocoa cake and cocoa powder. The implication of this is that as the cocoa production industry is expanding, the Theobroma cacao pods (TCP) which are the main by-products of cocoa processing are discarded as wastes hence constituting environmental pollution. Theobroma cacao pod (TCP) is a lignocellulosic waste consisting of cellulose 19.7-26.1\%, hemicellulose 8.7-12.8\% and lignin 14-28\% (Tsai et al., 2020).

Feldspar is a crystalline aluminosilicate minerals and appertains to the tectosilicate group that characterized by a larger density framework of layered silicate structure. It is the greatest and most abundant rock-forming mineral in the earth crust. It constitutes about $60 \%$ of igneous rocks. The mineralogical composition of feldspar consist of minerals such as orthoclase $\left(\mathrm{KAlSi}_{3} \mathrm{O}_{8}\right)$, albite $\left(\mathrm{NaAlSi}_{3} \mathrm{O}_{8}\right)$ and anorthite $\left(\mathrm{CaAl}_{2} \mathrm{Si}_{2} \mathrm{O}_{8}\right)$. In a considerable ratio of Feldspar ores, K-Feldspar (KAlSi ${ }_{3} \mathrm{O}_{8}$, microcline or orthoclase) and Na-Feldspar (albite, $\mathrm{NaAlSi}_{3} \mathrm{O}_{8}$ ) exist in the similar matrix (Yazdani et al., 2012). It has a formula $\mathrm{Si}_{4} \mathrm{O}_{8}$ but up to two of $\mathrm{Si}$ (VI) may be replaced by Al (III) with the charge deficiency balanced by large univalent cation. The feldspar surface is composed of negative and positive sites. The positive charges are $\mathrm{Na}^{+}$ ions in albite and $\mathrm{K}^{+}$ions in orthoclase, and the negative sites are nonpolar siloxane groups or polar silanol groups Awala and Jamal (2011). The inorganic cations at the surface of feldspar (e.g. $\mathrm{Na}^{+}, \mathrm{K}^{+}$and $\mathrm{Ca}^{2+}$ ) could be replaced by organic functional groups in Theobroma cacao pod (TCP), such as hydroxyl, carbonyl, carboxyl and methylene groups, through ion exchange, and hence improve the adsorption capacity of the feldspar surface in the modification process Unuabonah et al. (2013).

Indeed, large amounts of reports are available on the use of biosorbent materials, clay/aluminosilicate and biopolymer/clay composites for metal ion removal from aqueous solution. In contrast, there are virtually limited research reports on feldspar-biobased composites Unuabonah et al. (2013); Yazdani et al. (2014). Based on synergistic combinations of FS and TCP, the modified feldspar composite material have potential of a good adsorbent for varieties of pollutants in wastewater besides other industrial applications.

The present work is aimed at investigation of the adsorption of $\mathrm{Pb}$ (II) and $\mathrm{Cr}$ (VI) onto the modified composite (MFC) adsorbent using the experimental design and optimization of the adsorption parameter with application of Surface response methodology (RSM). The effects of initial $\mathrm{Pb}(\mathrm{II})$ and $\mathrm{Cr}(\mathrm{VI})$ concentration, adsorbent dose, solution $\mathrm{pH}$, and contact time were optimized, and the isotherm and kinetics of $\mathrm{Pb}$ (II) and $\mathrm{Cr}$ (VI) ions adsorption onto the novel adsorbent were also studied. 


\section{MATERIAL AND METHODS}

\subsection{COLLECTION AND PREPARATION OF ADSORBENTS}

\subsubsection{THEOBROMA CACAO PODS (TCP)}

The Theobroma cacao (Cocoa) pods were collected from cocoa plantations in Ifetedo town, Osun State. The TCP samples were washed thoroughly with tap water and then distilled water to remove dust and dirt. The samples were sun-dried and then ovendried at $70^{\circ} \mathrm{C}$ for $72 \mathrm{~h}$ to remove moisture. The dried TCP was ground in a mortar into powder. The powdered sample was sieved in a $0.230 \mathrm{~mm}$ sieve and stored in a precleaned dry air-tight plastic container (Olu-Owolabi et al., 2010; Sanusi and Umar (2016).

\subsubsection{FELDSPAR SAMPLE (FS}

The feldspar sample was obtained from the Federal Institute of Industrial Research Oshodi (FIIRO), Lagos, Nigeria. The sample was pre-treated by suspension in deionized water for $24 \mathrm{~h}$ and the suspension was carefully decanted to obtain the feldspar Unuabonah et al. (2013). The organic matter in the sample was removed by adding $30 \%$ hydrogen peroxide solution with stirring until effervescence ceased. The mixture was decanted and the feldspar washed with deionized water to remove all traces of hydrogen peroxide and then oven dried at $105{ }^{0} \mathrm{C}$ Adebowale et al. (2006). The sample sieved through a $230 \mathrm{~mm}$ mesh size sieve and stored in a pre-cleaned air-tight plastic container B. I. Olu-Owolabi et al. (2016).

\subsubsection{MODIFIED FELDSPAR COMPOSITE ADSORBENT (MFC}

Equal weight of feldspar and Theobroma cacao pods (50 g each) were weighed into a $500 \mathrm{~mL}$ beaker and $300 \mathrm{~mL}$ of $0.1 \mathrm{M} \mathrm{NaOH}$ was added. The content was thoroughly stirred and heated in an oven at $150{ }^{\circ} \mathrm{C}$ until dryness B. I. Olu-Owolabi et al. (2016). The samples of the dried mixtures were weighed into crucibles and calcined at 300 ${ }^{o} \mathrm{C}$ for $6 \mathrm{~h}$. The resulting dark powdery material was washed with deionized water to remove residual $\mathrm{NaOH}$ from the surface of the composite and subsequently ovendried at $105^{\circ} \mathrm{C}$ to remove all moisture. The dried sample was stored in an airtight container Unuabonah et al. (2013). It was subsequently referred to as Modified Feldspar Composite (MFC).

\subsubsection{SELECTION OF OPTIMUM THEOBROMA CACAO POD/FELDSPAR PERCENTAGE COMBINATION IN THE COMPOSITE PREPARATION}

In order to select the optimum percentage combination of feldspar (FS) and Theobroma cacao pod (TCP) in the novel composite (MFC), five different combos were prepared which comprise of 10\% TCP and 90\% FS (10FCP-90FS), 20\% TCP and 80\% FS (20TCP-80FS), 30\% TCP and 70\% FS (30TCP-70FS), 40\% TCP and 60\% 
FS (40TCP-60FS) and 50\% each of TCP and FS (50FCP-50FS). The procedure was followed so as to optimize the preparation of the composite (MFC) adsorbents Ogbu et al. (2019).

\subsection{CHARACTERIZATION OF ADSORBENTS}

The cation exchange capacity (CEC) of TCP, FS and MFC samples were determined using the ammonium acetate method as reported by Unuabonah et al. (2013). $\mathrm{Na}^{+}$and $\mathrm{K}^{+}$were determined using AES (Agilent PG 10T), while $\mathrm{Ca}^{2+}$ and $\mathrm{Mg}^{2+}$ were determined by atomic absorption spectrophotometer (SHIMAZU 360H Model). The summation of the exchangeable cations $\left(\mathrm{Ca}^{2+}, \mathrm{Mg}^{2+}, \mathrm{Na}^{+}\right.$, and $\mathrm{K}^{+}$) gave the cation exchange capacity (CEC). Unuabonah et al. (2013).

The functional groups present in the adsorbents (TCP, FS and MFC) were obtained using Shimadzu 8400S FTIR spectrometer operating on Platinum-Attenuated Total Reflectance (ATR) method. The samples were mounted on a diamond crystal disc and recorded with 20 scans in the frequency range of $4000-400 \mathrm{~cm}^{-1}$ with a resolution of $2 \mathrm{~cm}^{-1}$ Adebowale et al. (2006), Singh and Bhateria (2020).

The surface morphologies of the adsorbents were analyzed using scanning electron microscopy (SEM), Philips XL30 model. After gold coating (Philip J1050 sputter coater), the samples were placed in the SEM sample chamber where the micrographs of the TCP, FS and MFC were scanned and recorded at 32 scan and 15keV Hossain (2013); Dawood (2018).

The XRD spectra for TCP, FS and MFC were obtained using Agilent X-ray diffractometer with $\mathrm{Ni}$ filtered $\mathrm{CuK} \alpha$ radiation at $(\lambda=1.5406 \AA, 40 \mathrm{~mA}$ and $40 \mathrm{kV})$, a diffracted-beam graphite monochromator, and a detector Salih (2017). The X-ray diffractograms of TCP, FS and MFC were recorded by step scanning from $1.5^{\circ}$ to $50^{\circ}$

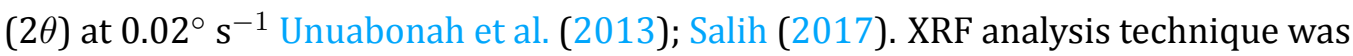
used in this study to determine the chemical composition of the TCP, FC and MFC adsorbents using Bruker AXS S4 Pioneer model X-ray fluorescence (XRF) Spectrometer with $60 \mathrm{kV}$ energy of the X-ray tube Unuabonah et al. (2013); Yazdani et al., 2012; Salih (2017).

Brunauer, Emmet and Teller (BET) results for specific surface area and porosity of adsorbents were obtained from adsorption/desorption isotherm of $\mathrm{N}_{2}$ at $77{ }^{0} \mathrm{~K}$ Hossain (2013); Unuabonah et al. (2013); Dawood (2018).

All experiments were carried out in triplicate for all the adsorbents prepared in the study.

\subsection{BATCH ADSORPTION EXPERIMENT}

Batch adsorption studies were carried out in $100 \mathrm{~mL}$ plastic bottles by contacting 0.5 g of adsorbent with $20 \mathrm{~mL}$ of $\mathrm{Pb}$ (II) and Cr (VI) solutions of $100 \mathrm{mg} / \mathrm{L}$ concentration. The adsorbent/metal ions mixtures were placed on a rotary shaker and shaken at $120 \mathrm{rpm}$ at a room temperature $\left(300^{\circ} \mathrm{K}\right)$ for a period of $150 \mathrm{~min}$ to attain equilibrium Chukwuemeka-Okorie et al. (2018). The effect of adsorption parameters such 
as adsorbent dose (0.5-3.0 g), $\mathrm{pH}(1 \pm 0.2$ to $8 \pm 0.2)$ contact time (15-300 $\mathrm{min})$ and adsorbate concentration (50-300 mg/L) were investigated for $\mathrm{Pb}$ (II) and $\mathrm{Cr}$ (VI) onto FS and MFC adsorbents. On completion of experimental time, the sample mixtures were filtered using whatman 0.45 micron filter paper and the filtrates were be analyzed for the concentration of the metal ions left in solutions using atomic absorption spectrophotometric (AAS) method Unuabonah et al. (2013); Anusa et al. (2017). All adsorption experiments were carried out in triplicate for all the four metals studied.

\subsection{OPTIMIZATION OF ADSORPTION PARAMETERS}

A standard response surface methodology (RSM) design, central composite design (CCD), was utilized to determine the optimum set of adsorption process variables, and this includes three steps of experimental design, response surface modeling, and process optimization. Generally, in a 5 level study. The CCD consists of $2^{n}$ factorial runs, $2 n$ axial runs (indeed these $2 n$ points fixed axially at a distance, $\alpha$, from the center to produce the quadratic terms), and $n_{c}$ center runs $\left(2^{n}+2 n+n_{c}\right)$, where $n$ is the number of adsorption parameters.

Number of experiments $(N)=\left(2^{n}+2 n+n_{c}\right)=16+(2 \times 4)+8=3232$

\subsubsection{DESIGN OF EXPERIMENT USING RESPONSE SURFACE METHODOLOGY}

Design-Expert 12 software ("MiniTab" version 15) was applied in the design of experiment. In the design process, four factors (adsorption parameters) were considered for optimization, viz; initial metal concentrations (50-150 mg/L), $\mathrm{pH}$ (2-8), adsorbent dosage (0.5-2.5g) and contact time (30-210 $\mathrm{min}$ ) and adsorption efficiencies of $\mathrm{Pb}$ (II) and $\mathrm{Cr}$ (VI) ions onto MFC (response).

Table 1 Adsorption parameters (Independent variables) and their corresponding coded levels

\begin{tabular}{ccccc}
\hline Independent variables & Ranges and Coded Levels & & \\
\hline Initial metal conc. $\left(\mathrm{C}_{0}\right)(\mathrm{mg} / \mathrm{L})$ & 50 & -10 & +1 & $+\alpha$ \\
$\mathrm{pH}$ & 2 & 75100 & 125 & 150 \\
\hline Adsorbent dose (D) (g) & 0.5 & 35 & 6 & 8 \\
\hline Contact time (T)(min) & 30 & 11.5 & 2 & 2.5 \\
\hline
\end{tabular}

\subsubsection{DETERMINATION OF EFFECT OF INTERACTION OF ADSORPTION PARAMETERS (FACTORS)}

A quadratic model in form of expression below was developed for the adsorption of the metal as it was influenced by the adsorption parameters considered during the experiments. The response model may be represented as 


$$
Y=\beta_{0}+\sum_{i=1}^{n} \beta_{i} X_{i}+\sum_{i=1}^{n} \beta_{i i} X_{i}^{2}+\sum_{i=1}^{n-1} \sum_{j=i+1}^{n} \beta_{i j} X_{i} X_{j}
$$

Where $Y$ is the response, and the objective is to optimize the response $(Y) \cdot \beta_{0}$ is the constant coefficient, is $\beta_{i}$ the linear coefficients, $\beta_{i i}$ is the quadratic coefficients, $\beta_{i j}$ is the interaction coefficients, and $X_{i}$ and $X_{j}$ are the coded values of the independent process variables. Coefficient of determination $\left(\mathrm{R}^{2}\right)$ was used to determine the quality of the model as it compared the data from predicted model with data got from experimental runs (Yazdani et al., 2013; Adetokun et al. (2019).

\subsection{DATA TREATMENT}

The amount of metal ions adsorbed per gram of FS and MFC was calculated using equation 1.

$$
q_{e}=\frac{\left(C_{0}-C_{e}\right) V}{M}
$$

Where; and are the initial and final metal ion concentrations in solutions; , $V$ and $\mathrm{M}$ are the amount of metal ions adsorbed ( $\mathrm{mg} / \mathrm{g}$ ), volume of the solution ( $\mathrm{mL}$ ) used for experiment and mass ( $\mathrm{g}$ ) of sample, respectively.

The percentage removal of metal ions by FS and MFC was calculated using the equation 2 .

$$
\% \mathrm{R}=\frac{C_{o}-C_{e}}{C_{o}} \times 100
$$

Where; $\mathrm{R}$ is the removal efficiency of the metal ions adsorbent studied; $\mathrm{C}_{O}$ is the initial metal ions concentration in solution $(\mathrm{mg} / \mathrm{L}) ; C_{e}$ is the metal ions concentration removed or adsorbed by adsorbent at equilibrium $(\mathrm{mg} / \mathrm{L})$.

\subsection{ADSORPTION ISOTHERM MODELS}

The relationship between the amount of $\mathrm{Pb}$ (II) and $\mathrm{Cr}$ (VI) ions adsorbed onto the adsorbents (FS and MFC) and their equilibrium concentrations in aqueous solution were evaluated using of Langmuir and Freundlich models.

The Langmuir isotherm is represented by the equation 3 .

$$
q_{\mathrm{e}}=\frac{Q_{\mathrm{o}} b C_{\mathrm{e}}}{1+b C_{\mathrm{e}}}
$$


or its linear form in equation 4.

$$
\frac{C_{\mathrm{e}}}{q_{\mathrm{e}}}=\frac{1}{Q_{\mathrm{o}} b}+\frac{C_{\mathrm{e}}}{Q_{\mathrm{o}}}
$$

When $\frac{C_{e}}{q_{e}}$ is plotted against $\mathrm{C}_{e}$, the slope is equal to $\frac{1}{Q_{o}}$ and the intercept is equal to $\frac{1}{Q_{o^{b}}}$

The essential characteristics of the Langmuir isotherm can be expressed in terms of a dimensionless constant separation factor or equilibrium parameter (RL) which is defined by:

$$
R_{\mathrm{L}}=1 /\left(1+b C_{0}\right)
$$

Where $\mathrm{b}$ is the Langmuir constant and $\mathrm{C}_{0}$ the highest metal ion concentration $(\mathrm{mg} / \mathrm{L})$. The value of $\mathrm{R}_{L}$ indicates the type of the isotherm to be either unfavourable $\left(\mathrm{R}_{L}>1\right)$, linear $\left(\mathrm{R}_{L}=1\right)$, favourable $\left(0<\mathrm{R}_{L}<1\right)$ or irreversible $\left(\mathrm{R}_{L}=0\right)$.

The Freundlich isotherm is represented by equation 6 .

$$
q_{\mathrm{e}}=K_{\mathrm{f}} C_{\mathrm{e}}^{\mathrm{n}}
$$

or its linear form in equation 7.

$$
\log q_{e}=\log K_{F}+\left(\frac{1}{n}\right) \log C_{e}
$$

7

The values of $K_{f}$ and $\mathrm{n}$ may be calculated by plotting $\log \left(q_{e}\right)$ versus $\log \left(C_{e}\right)$. The slope is equal to $\frac{1}{n}$ and the intercept is equal to $\log \left(K_{f}\right)$.

Where is the maximal adsorption capacity per unit weight of adsorbent, b is a solute-surface interaction energy-related parameter, while and are the amount of metal ions adsorbed (mg/g) and metal ions concentrations in solutions after the equilibrium; where and $\mathrm{n}$ are the Freundlich model capacity factor and the isotherm linearity parameter respectively Saeed et al. (2005); Das and Mondal, 2011)).

\subsection{ADSORPTION KINETIC MODELS}

Four adsorption kinetics models were employed in describing the adsorption experiment data in order to examine the mechanism of the adsorption process. These are the Lagergren pseudo-first-order (PFO), pseudo second-order (PSO), intra-particle diffusion and Elovich models.

The equations are expressed below:

PFO:

$$
\log \left(q_{e}-q_{t}\right)=\log q_{e}-\frac{k_{1}}{2.303} t
$$


PSO:

$$
\frac{t}{q_{t}}=\frac{1}{k_{2} q_{e}^{2}}+\frac{t}{q_{e}}
$$

Elovich:

$$
\mathrm{q}_{\mathrm{t}}=\frac{1}{\beta} \operatorname{Ln}(\alpha \beta)+\frac{1}{\beta} \operatorname{Ln}(\mathrm{t})
$$

Where $\mathrm{q}_{e}$ and $\mathrm{q}_{t}$ are adsorption quantity $(\mathrm{mg} / \mathrm{g})$ at equilibrium and at time $\mathrm{t}$, respectively; $\mathrm{k}_{1}$ and $\mathrm{k}_{2}$ are the rate constants $\left(\mathrm{min}^{-1}\right.$ ) of the PFO and PSO, respectively; ) is the rate parameter of the intra-particle diffusion control stage; $\alpha$ is the initial adsorption rate $(\mathrm{mg} / \mathrm{g} / \mathrm{min})$ and is related to the extent of surface coverage and activation energy for chemisorption $(\mathrm{g} / \mathrm{mg})$.

The $\mathrm{q}_{e}$ and rate constants were calculated from the slope and intercept of the plots of $\log \left(\mathrm{q}_{e}-\mathrm{q}_{t}\right)$ vs. $\mathrm{t}$; and $\mathrm{t} / \mathrm{q}$ vs. $\mathrm{t}$ for PFO and PSO respectively. From equation 10, a plot of and interceptadsorption mechanism is in line with the intra-particle diffusion process. If the intra-particle diffusion process is the predominant rate-limiting step in the adsorption, the plot would pass through the origin B. I. Olu-Owolabi et al. (2016) Sanusi and Umar (2016).

\section{RESULT AND DISCUSSION}

\subsection{T EST FOR THE PERFORMANCE OF MODIFIED FELDSPAR COMPOSITE (MFC) FOR METAL ADSORPTION}

The adsorbents were utilized for the adsorption of the metal ions from the aqueous solution at metal concentration $100 \mathrm{mg} / \mathrm{L}$ as shown in Figure 1 . It was observed that an increase in percentage adsorption and adsorption capacity of the metal ions with increase in the amount of TCP in the composite were obtained. However, 50TCP-50FS recorded the highest percentages for $\mathrm{Pb}(97.8 \%)$ and $\mathrm{Cr}$ (92.1\%) respectively. In general, the increase in metal adsorption with TCP concentration is possibly due to increase in the number of active binding sites on the MFC and improved heterogeneous nature of the adsorbent. The 50TCP-50FS composite adsorbent was chosen and utilized in this study for adsorption due to its relatively higher adsorption potential recorded than the other composite mixtures. 


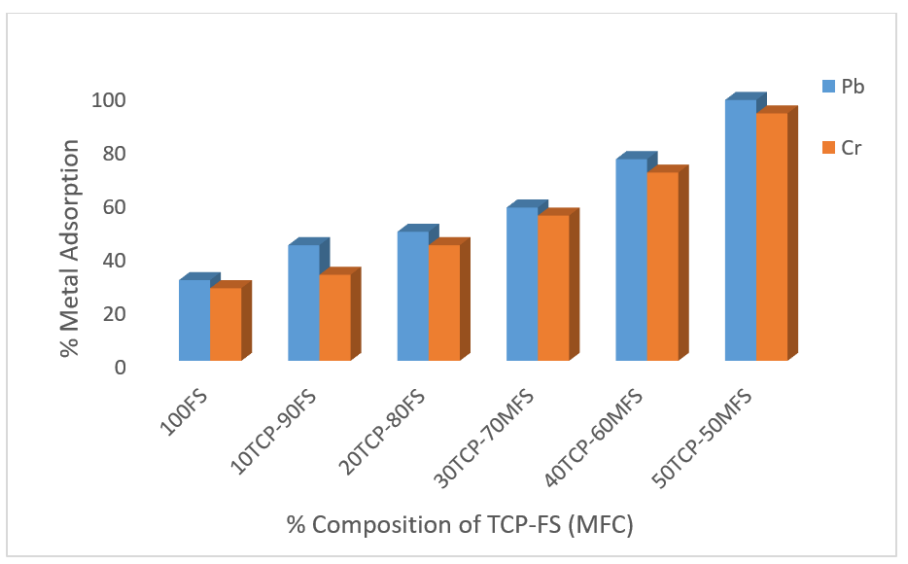

Figure 1 Optimization of Theobroma cacao-feldspar mixtures and calcination on the adsorption of $\mathrm{Pb}$ (II) and $\mathrm{Cr}(\mathrm{VI})$ from solution.

\subsection{HARACTERIZATION OF ADSORBENTS}

\subsubsection{ATION EXCHANGE CAPACITY (CEC)}

From the results in Table 2, MFC had the higher value for CEC $(30.66 \pm 0.21$ meq $/ 100 \mathrm{~g})$ compared to FS $(6.42 \pm 0.45 \mathrm{meq} / 100 \mathrm{~g})$. The results indicated that MFC, a composite resulting from the combination of FS and TCP has improved ion-exchange capacity from the surface modification process.

Table 2 The pH andCation Exchange Capacity of the FS and MFC

\begin{tabular}{|c|c|c|c|c|c|c|}
\hline \multirow[t]{2}{*}{$\begin{array}{l}\text { Adsor- } \\
\text { bents }\end{array}$} & \multirow[t]{2}{*}{ pH } & \multicolumn{2}{|c|}{$\begin{array}{c}\text { Exchangeable } \\
\text { cations(meq/100g) }\end{array}$} & & & \multirow[t]{2}{*}{$\begin{array}{c}\text { CEC } \\
\text { (meq/100g }\end{array}$} \\
\hline & & $\mathrm{Ca}$ & Mg & K & $\mathrm{Na}$ & \\
\hline FS & $4.95 \pm 0.36$ & $1.08 \pm 0.1$ & $0.45 \pm 0.02$ & $3.31 \pm 0.4$ & $1.58 \pm 0.23$ & $6.42 \pm 0.45$ \\
\hline MFC & $7.60 \pm 0.01$ & $5.57 \pm 0.9$ & $3.85 \pm 0.00$ & $13.88 \pm 0.5$ & $7.36 \pm 0.99$ & $30.66 \pm 0.21$ \\
\hline
\end{tabular}

\subsubsection{FOURIER TRANSFORM INFRARED (FTIR SPECTROSCOPY ANALYSIS}

The infrared spectra of TCP, FS, and MFC were shown in Figures 2, 3 and 4. FTIR spectra of TCP showed several absorption peaks between the scanning frequency ranges of $4000-500 \mathrm{~cm}^{-1}$. The peak exhibit a broad and strong $-\mathrm{OH}$ band at 3479 $\mathrm{cm}^{-1}$ indicating the presence of hydroxyl, phenolic or carboxylic $-\mathrm{OH}$ stretching vibration as typical of cellulose and lignin (i.e. free hydroxyl groups in the polysaccharide structure of its wall). The strong band at $3408 \mathrm{~cm}^{-1}$ is a $-\mathrm{N}-\mathrm{H}$ stretching indicative of vibration associated with $\mathrm{N}$ - substituted amide. The two sharp absorption bands at 2923 and $2854 \mathrm{~cm}^{-1}$ showed the presence of C-H stretch likely from aliphatic (methyl and methylene) groups. The sharp band appearing at $1747 \mathrm{~cm}^{-1}$ is characteristic of typical $\mathrm{C}=0$ stretch bond from either a free acid or esterified 
carboxyl group. However, a distinct absorption band at $1651 \mathrm{~cm}^{-1}$ is assigned to a $\mathrm{C}=0$ stretching vibration of carbonyl group. The strong band appearing at 1380 $\mathrm{cm}^{-1}$ suggests a carboxylate ester. Moreover, the prominent band at $1057 \mathrm{~cm}^{-1}$ is associated with the $\mathrm{C}-\mathrm{O}$ bond or $-\mathrm{C}-\mathrm{C}-$ stretching such as glycosidic linkage which are characteristic of polysaccharides. Similar observations have been reported by Pehlivan et al. (2007), Olu-Owolabi et al. (2012b), and Unuabonah et al. (2013).

The FT-IR spectra of feldspar (FS) exhibit a strong band at at $3670 \mathrm{~cm}^{-1}$ indicative of the presence of hydroxyl group ( $-\mathrm{OH}$ stretching vibration) lying between the octahedral sheets in the feldspar mineral surface. This peak at $3670 \mathrm{~cm}^{-1}$ is characteristic of $-\mathrm{OH}$ group residing at the surface of the layer that form weak hydrogen bonds with oxygen of the $\mathrm{Si}-\mathrm{O}-\mathrm{Si}$ bonds on the lower surface of the next layer. The absorption peaks noticed at 3447 and $1637 \mathrm{~cm}^{-1}$ are $\mathrm{H}-\mathrm{O}-\mathrm{H}$ stretching and bending vibrations from absorbed water. The strong peak at $1366 \mathrm{~cm}^{-1}$ is suggestive of Si-O stretching vibration band. Bands at 1067 and $952 \mathrm{~cm}^{-1}$ correspond to the $\mathrm{Si}-\mathrm{O}$ and $\mathrm{Al}-\mathrm{OH}$ in plane bending vibrations, respectively. The peaks at 993 and $767 \mathrm{~cm}^{-1}$ were attributed to $\mathrm{SiO}_{2}$ and $\mathrm{Al}-\mathrm{OH}$ deformation. The two medium but weak peaks at 615 and $559 \mathrm{~cm}^{-1}$ indicate the presence of Si-O stretching as well as -OH bending vibration respectively. FT-IR spectra analysis confirmed that the aluminosilicate material composed of feldspar Awala and Jamal (2011), 2011; Unuabonah et al. (2013) and Yazdani et al. (2014).

For the MFC adsorbent, as it could be seen (Figure 4), changes in the absorption bands of the feldspar after TCP modification were observed in the spectrum which is an indication of the successful modification of the adsorbent. The absorption band of the TCP/feldspar (MFC) appearing at 3432 and $3696 \mathrm{~cm}^{-1}$ has been enhanced, which resulted from vibration bands of TCP $(\mathrm{O}-\mathrm{H}$ and $\mathrm{N}-\mathrm{H}$ stretching) overlap with the bands of feldspar (-OH stretching of $\mathrm{H}_{2} \mathrm{O}$ ). The bands at $2928,2849 \mathrm{~cm}^{-1}$ and $1380 \mathrm{~cm}^{-1}$ related to the intercalated TCP $\left(-\mathrm{CH}_{2}\right.$ stretching and $\mathrm{C}-\mathrm{H}$ bending on methyl and methylene groups) are seen in the spectra of the bio-based (MFC) composite Unuabonah et al. (2013). The Si-O bending vibration observed at $1034 \mathrm{~cm}^{-1}$ showed a significant shift when compared to that of the raw feldspar. This suggests that the peak position is perhaps one of the active sites for interaction of the feldspar with the TCP biomass (Dawodu and Akpomie, 2014). The band at 1626 $\mathrm{cm}^{-1}$ attributed to the deformation vibration of the protonated amine group $(-\mathrm{N}-$ H) of TCP was also observed in the MFC. The intensity of the band at $1626 \mathrm{~cm}^{-1}$ of the MFC spectra has increased with a pronounced band shift from the original constituent materials, indicating the first $\mathrm{NH}-\mathrm{CO}$ group stretching vibration of TCP overlap with $-\mathrm{OH}$ bending vibration of $\mathrm{H}_{2} \mathrm{O}$ in the interlayer of feldspar. More so, corresponding to the vibration bands of silicates, and other adsorption bands are relatively similar to those of the feldspar sample with only slight shift indicating the MFC adsorption active sites responsible for binding of metal ions Ogbu et al. (2019). Overall, FTIR spectra confirmed that the MFC is indeed a composite consisting of feldspar (FS) and Theobroma cacao pod (TCP). 


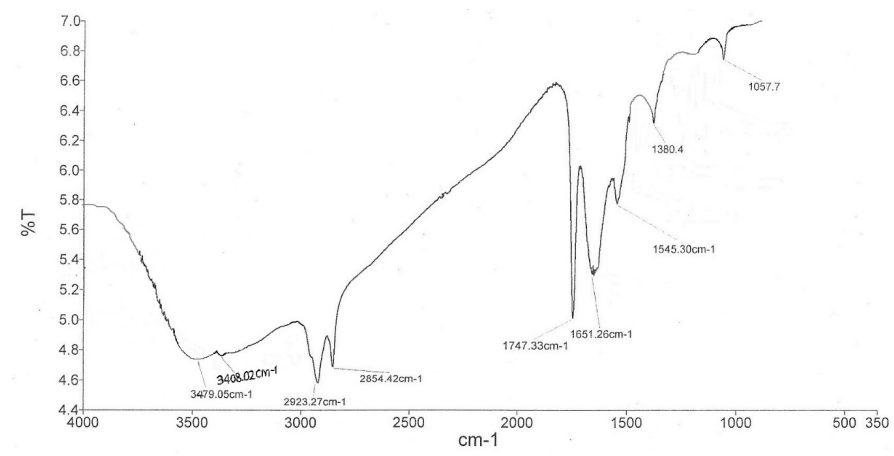

Figure 2 FTIR Spectra of Theobroma cacao pod (TCP).

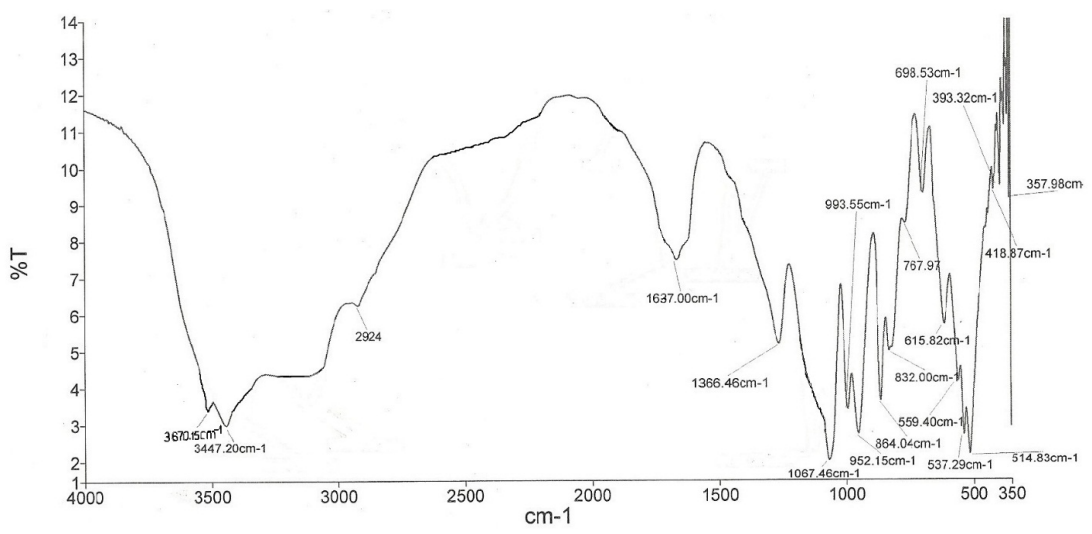

Figure 3 FTIR Spectra of unmodified feldspar (FS)

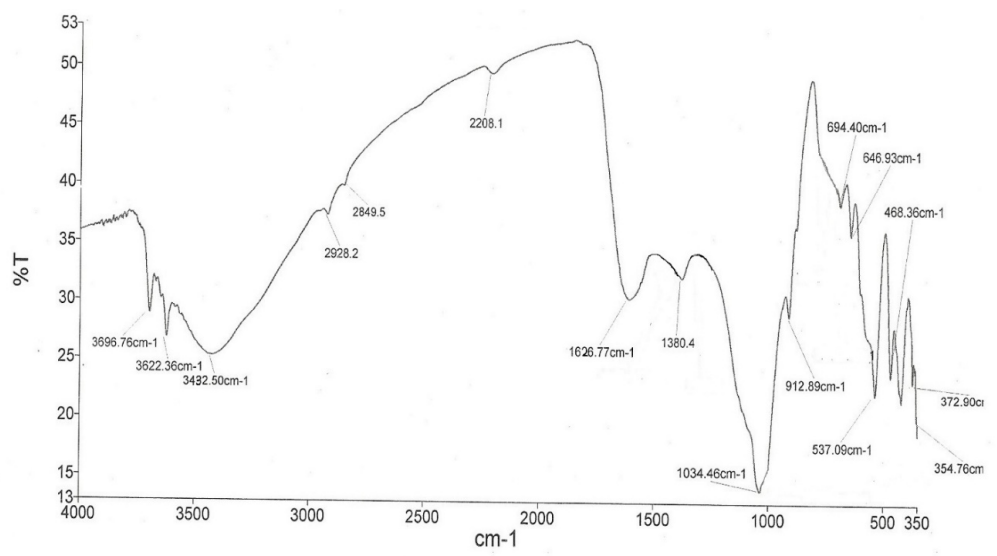

Figure 4 FTIR Spectra of modified feldspar composite (MFC) 
Table 3 X-ray fluorescence analysis of feldspar (FS), Theobroma cacao pod (TCP), and MFC.

\begin{tabular}{lll}
\hline \% Oxide & FS (\%) & MFC (\%) \\
$\mathrm{SiO}_{2}$ & $63.20 \pm 0.45$ & $60.20 \pm 0.50$ \\
$\mathrm{Al}_{2} \mathrm{O}_{3}$ & $16.00 \pm 0.33$ & $10.90 \pm 0.01$ \\
$\mathrm{Na}_{2} \mathrm{O}$ & $5.13 \pm 0.12$ & $6.13 \pm 0.00$ \\
$\mathrm{~K}_{2} \mathrm{O}$ & $9.76 \pm 0.88$ & $10.76 \pm 0.35$ \\
$\mathrm{CaO}$ & $2.17 \pm 0.10$ & $2.17 \pm 0.77$ \\
$\mathrm{Fe}_{2} \mathrm{O}_{3}$ & $0.49 \pm 0.00$ & $0.40 \pm 0.14$ \\
$\mathrm{TiO}_{2}$ & $\mathrm{ND}$ & $\mathrm{ND}$ \\
$\mathrm{MgO}_{\mathrm{LOI}}$ & $1.37 \pm 0.99$ & $1.37 \pm 0.31$ \\
\hline $\mathrm{ND}=\mathrm{BELOW}$ & $0.06 \pm 0.46$ & $0.06 \pm 0.22$ \\
\hline
\end{tabular}

\subsubsection{X-RAY FLUORESCENCE (XRF ANALYSIS)}

Showed the results obtained from X-ray fluorescence (XRF) analysis of the adsorbents. XRF detected only a slight change in the $\mathrm{Si} / \mathrm{Al}$ ratio before and after modification of the feldspar. MFC has a higher silica to alumina ratio (5.52) than the FS (3.95) which might be associated with the leaching of silicon and aluminum by base treatment during the surface modification process Unuabonah et al. (2013). From XRF results, it was observed that the percentage composition of $\mathrm{K}$ is higher than $\mathrm{Na}$ and Ca in the feldspar sample, suggesting an orthoclase (K- feldspar) Awala and Jamal (2011). XRF also finds a number of other elements (Fe, Ca and $\mathrm{Mg}$ ) that are typical of the raw feldspar Unuabonah et al. (2013) and Yazdani et al., 201). XRF did, however, detected the elements only at low levels in TCP except for K and Ca which are essential minerals.

\subsubsection{X-RAY DIFFRACTION (XRD ANALYSIS)}

X-ray diffraction (XRD) analysis of the FS sample showed that it is a feldspar containing orthoclase, microcline and quartz Figure 5 . This suggests that the feldspar has two variety (phases) of K-feldspar minerals; the orthoclase (0) and microcline (M) Unuabonah et al. (2013). The reflections at $20.08^{\circ}(2 \theta)(3.83 \AA, 201)$ and $25.6^{\circ}$

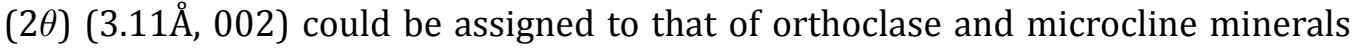
respectively. The reflections at at $20.08^{\circ}(2 \theta)(3.83 \AA, 201), 25.6^{\circ}(2 \theta)(3.11 \AA .002)$ and $27.80^{\circ}(2 \theta)(2.89 \AA, 040), 30.44^{\circ}(2 \theta)(2.67 \AA, 1 \overline{3} 1)$ indicated that the crystals of the feldspar sample used in this study were partly monoclinic and partly triclinic Unuabonah et al. (2013). The reflection at $26.60^{\circ}(2 \theta)$ is from quartz $(3.00$ $\AA, 131)$, which is also present in the raw material. The XRD pattern of feldspar showed typical diffraction peaks at $2 \theta=13.25$ (6.6 $)$ ) and $14.40 \circ(6.14 \AA$ ), whereas, after incorporating with TCP, these peaks shift to lower angles and even disappear. The disappearance of the feldspar reflection at $2 \theta=14.40^{\circ}$ and the appearance of 
a new reflection at $11.25^{\circ} 2 \theta$ in the XRD pattern of MFC composite showed that intercalation has occurred Yazdani et al. (2014). These results suggested that the order along the crystallographic c-axis of feldspar is slightly disturbed by the reaction between the TCP and the FS. The rest of the crystal structure is not affected by the MFC preparation process, indicating that the crystallography of the individual aluminosilicate layers is not affected. Similar observation was reported Ofomaja et al. (2007), Unuabonah et al. (2013). The XRD patterns of the TCP with two broad and overlapping reflections essentially indicate a low order structure. Correspondingly, the XRD patterns of the MFC have increased intensity than those of the FS indicating that the incorporation of TCP via calcination cause little orderliness in the resulting MFC material, presumed by disturbing the interlayer geometry between individual feldspar mineral layers. This likely confirmed the disordered intercalation in MFC composite as reported Sanusi and Umar (2016).

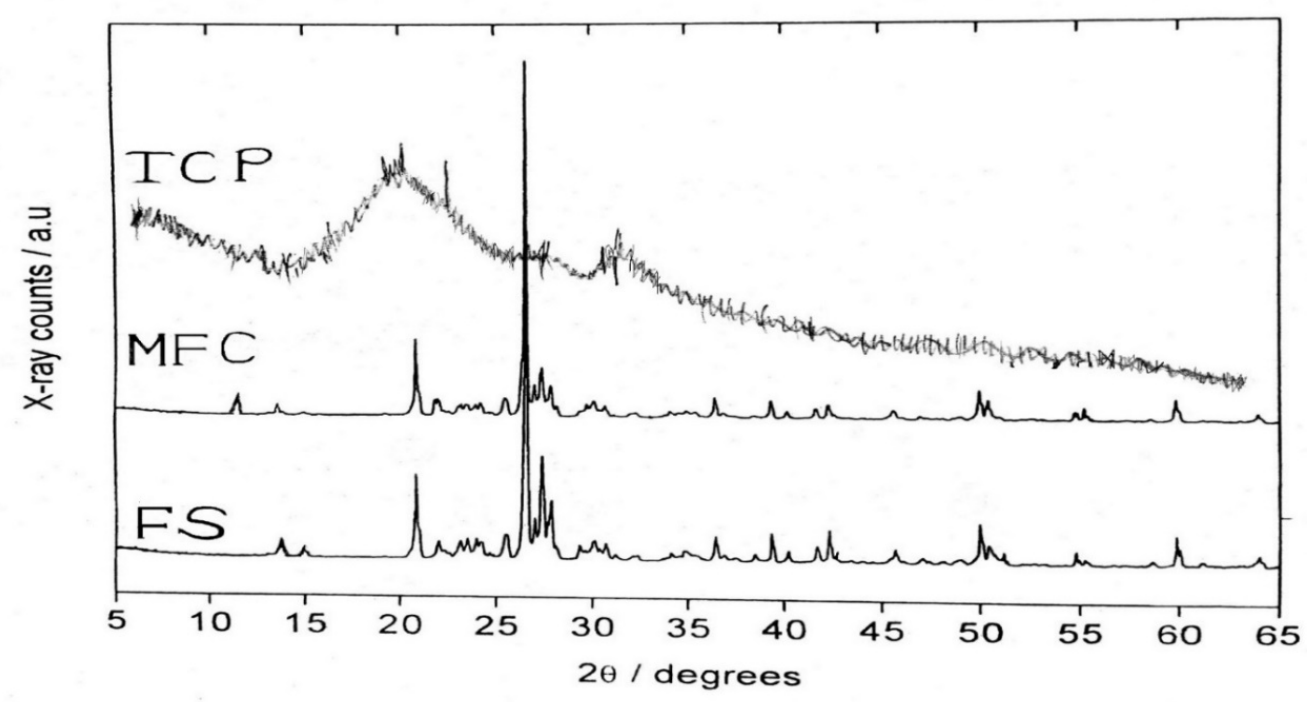

Figure 5 XRD patterns of TCP, FS and MFC adsorbents.

\subsubsection{SEM ANALYSIS}

Figures 6 and 7 showed scanning electron microscopy (SEM) of FS and MFC respectively. The SEM is used to examine the surface morphology and the porous nature of the material responsible for adsorption of metal ions. The SEM images supported the XRD results, as there was no significant morphological disparity between the FS and MFC. Both adsorbents are porous, consisted of considerable number of heterogeneous pores, irregular surface and particle aggregation of various shapes and sizes with relatively flat facets, which is typical of feldspar mineral Awala and Jamal (2011) 
and Ogbu et al. (2019). The presence of pores helps in the diffusion of metal ions into the adsorbents during the adsorption of metal ions from solution (Dawodu and Akpomie, 2014). Also, the SEM images of FS and MFC showed some white clumps or particles on the surface, these were probably due to the presence of non-clay minerals like potassium, magnesium, sodium and calcium Ogbu et al. (2019). From the image of MFC (Figure 7), it was observed that the bio-based composite smaller particle sizes compared to the raw feldspar.

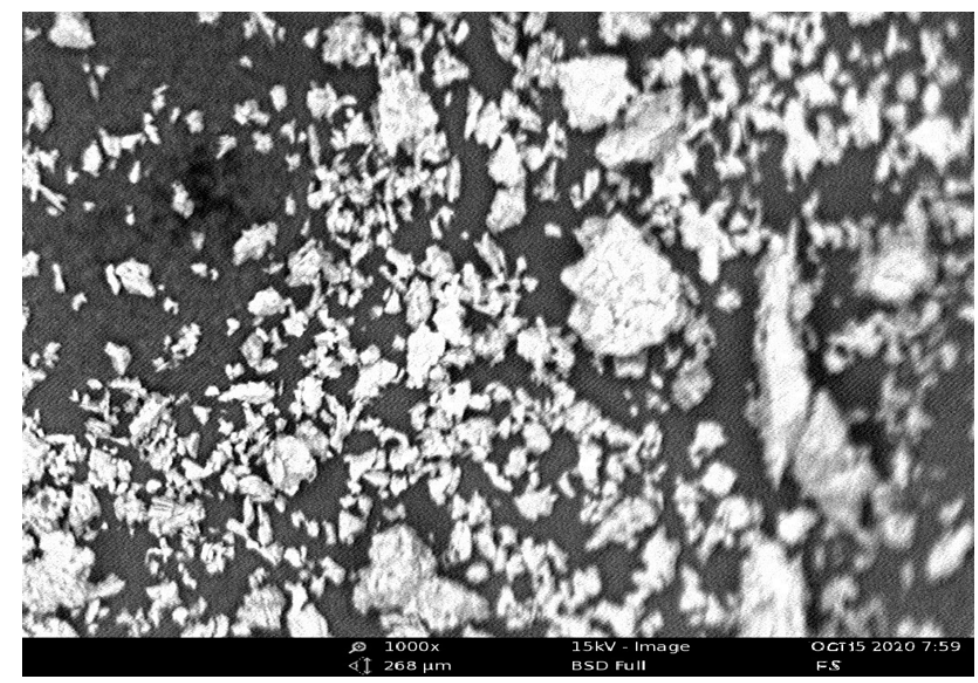

Figure 6 Scanning Electron Micrograph of FS

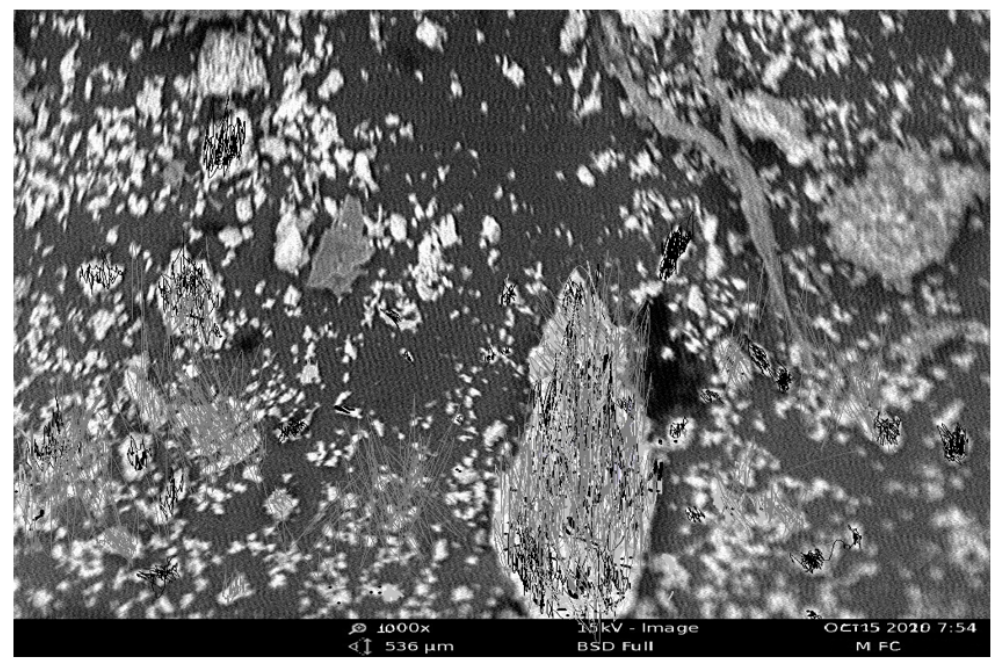

Figure 7 Scanning Electron Micrograph of MFC 


\subsubsection{BET SURFACE AREA AND PARTICLE SIZE ANALYSIS}

The results of cation exchange capacity (CEC) (Table 2 ) and the surface area (SA) (Table 4 ) supported the FTIR, XRF, XRD, and SEM images. The results reflected the similarities and differences between the FS and MFC. The MFC adsorbent showed an increased surface area $\left(53.60 \pm 0.3 \mathrm{~m}^{2} / \mathrm{g}\right)$ compared to FS $\left(21.56 \pm 0.1 \mathrm{~m}^{2} / \mathrm{g}\right)$, suggesting that the new material has the smallest particle sizes. This is supported by the results of particle size analysis of the adsorbents in which FS and TCP particles sizes decreased from a mean size of $162.8 \mu \mathrm{m}(\mathrm{FS})$ to $105.4 \mu \mathrm{m}$ for the MFC adsorbent. Finally, the CEC increased from $6.42 \pm 0.45 \mathrm{meq} / 100 \mathrm{~g}$ (FS) to $30.66 \pm 0.21 \mathrm{meq} / 100$ $\mathrm{g}(\mathrm{MFC})$ upon functionalization. The narrow pore diameter $(8.571 \pm 0.11 \mathrm{~nm})$ for MFC has indicated a micropore dimension as improvement from feldspar mesopores $(30.65 \pm 0.03 \mathrm{~nm})$. These mesopores were responsible for transporting metal ions into the micropores of MFC, consequently improving the adsorption capacity of the MFC Ogbu et al. (2019).

\begin{tabular}{|c|c|c|}
\hline Parameters & FS & MFC \\
\hline Specific surface area $\left(\mathrm{m}^{2} / \mathrm{g}\right)$ & $21.56 \pm 0.10$ & $53.60 \pm 0.30$ \\
\hline Average pore diameter (nm) & $30.65 \pm 0.03$ & $8.571 \pm 0.11$ \\
\hline Total pore volume $\left(\mathrm{cm}^{3} / \mathrm{g}\right)$ & $0.470 \pm 0.00$ & $0.253 \pm 0.05$ \\
\hline Particle size $(\mu \mathrm{m})$ & $162.8 \pm 0.16$ & $105.4 \pm 0.18$ \\
\hline BET Analysis Results & & UCL UMYU-KATSINA \\
\hline
\end{tabular}

Overall, FTIR, XRF, XRD and SEM confirmed that the composite (MFC) was essentially identical to the feldspar (FS) starting material; a tectosilicate with only slight modification. These observations were reported in a similar studies by Awala and Jamal (2011); Unuabonah et al. (2013) and Yazdani et al. (2014), Sanusi and Umar (2016).

\subsection{EFFECT OF OPERATING PARAMETERS ON METAL ADSORPTION}

\subsubsection{EFFECT PH OF THE SOLUTION METAL ADSORPTION}

The solution $\mathrm{pH}$ is an important adsorption parameter because it affects the activities of functional groups present on the surface of the adsorbents which are responsible for adsorption, and initiate competitive adsorption of metal ions onto adsorption active sites B. Olu-Owolabi et al. (2012); Sanusi and Umar (2016). Establishing the capacity of FS and MFC as novel adsorbents for $\mathrm{Pb}$ (II) and $\mathrm{Cr}$ (VI) ions required the knowledge of optimum pH for adsorption. As shown in Figures 8 and 9 , the uptake of $\mathrm{Pb}$ (II) and $\mathrm{Cr}$ (VI) is $\mathrm{pH}$ dependent. For $\mathrm{Pb}$ (II) removal, at highly acidic (low) $\mathrm{pH}$ values ( $\mathrm{pH} 1.0-2.0$ ), the surface of the adsorbents and the solutions were associated with the excess of $\mathrm{H}^{+}$ions, hence competition between the metal cations and $\mathrm{H}^{+}$ions for the active adsorption sites on the surface of the adsorbents lead to a decrease in 
uptake and the removal of metal ions Chukwuemeka-Okorie et al. (2018); Ogbu et al. (2019). This lower metal adsorption, specifically at pH 1 could also be attributed to the lower stability of some the metal cations bound to the active sites and then easily released in an extremely high acidic media (Egila et al., 2010). As pH value increased, the surface of the FS and MFC became more negatively charged and hence electrostatic attraction between the metal cations and adsorbents surface active sites increased. This reduced the competition between the metals and $\mathrm{H}^{+}$ions for the active sites of the adsorbents leading to an increase in percentage adsorption Adebowale et al. (2006); Chukwuemeka-Okorie et al. (2018). With an increase in initial solution $\mathrm{pH}$ from 2.0 to 8.0, the percentage adsorption of $\mathrm{Pb}$ (II) increased from 43.09 to 74.59 , and 65.12 to $98.98 \%$, for FS and MFC respectively. However, for $\mathrm{pH}$ values greater than 6.0, there is probability of metal precipitation from solution in the form of hydroxides and this usually accounts for the higher removal recorded at $\mathrm{pH} 7.0$ and 8.0 (Akpomie and Dawodu, 2014).

Conversely, for $\mathrm{Cr}$ (VI) ions adsorption at $\mathrm{pH}$ (1-8), results (Figure 9 ) showed that adsorption efficiency and adsorption capacity of all the adsorbents for $\mathrm{Cr}(\mathrm{VI})$ ions uptake reached maximum values at a lower $\mathrm{pH}$ 2. The amount of $\mathrm{Cr}$ (VI) adsorbed by FS and MFC were $2.978 \mathrm{mg} / \mathrm{g}(72.45 \%)$ and $3.619 \mathrm{mg} / \mathrm{g}(90.47 \%)$ respectively at $\mathrm{pH}$ 2. From $\mathrm{pH} 3$, the percentage $\mathrm{Cr}(\mathrm{VI})$ uptake decreased considerably with increase in $\mathrm{pH}$ value. The highest adsorption of $\mathrm{Cr}(\mathrm{VI})$ ions recorded at $\mathrm{pH} 2$ may be attributed to the electrostatic attraction between the adsorbents and the two different adsorbate species in aqueous solution at the lower pH. Chromium exists mostly in two oxidation states which are $\mathrm{Cr}$ (VI) and $\mathrm{Cr}$ (III) and the stability of these ionic forms is dependent on the $\mathrm{pH}$ of the aqueous solution. At low $\mathrm{pH}$, the predominant species of $\mathrm{Cr}$ (VI) are $\mathrm{Cr}_{2} \mathrm{O}_{7}{ }^{2-}, \mathrm{HCrO}_{4}{ }^{-}$and $\mathrm{CrO}_{4}{ }^{2-}$ while the surface of the adsorbent becomes protonated and attracts anionic species i.e $\mathrm{HCrO}_{4}{ }^{-}$Sanusi and Umar (2016); Ogbu et al. (2019). Increasing the $\mathrm{pH}$ will shift the concentration of $\mathrm{HCrO}_{4}{ }^{-}$to other forms, $\mathrm{CrO}_{4}{ }^{2-}$ and $\mathrm{Cr}_{2} \mathrm{O}_{7}{ }^{2-}$. Maximum adsorption at $\mathrm{pH} 2$ indicated that the $\mathrm{HCrO}_{4}{ }^{-}$ form of $\mathrm{Cr}(\mathrm{VI})$ is the dominant species at lower $\mathrm{pH}$ values which is preferentially adsorbed onto the FS and MFC surfaces. Similar observation was reported Demirbas (2004); Chukwuemeka-Okorie et al. (2018).

Comparing adsorption of metals at optimum $\mathrm{pH}$ values on all the adsorbents, the adsorption trend of $\mathrm{Pb}$ (II) < Cr (VI) may be attributed to differences in behaviour of metal ions in the aqueous solution such as the smaller hydrated radius of $\mathrm{Pb}$ (II) (0.401 nm) compared to $\mathrm{Cr}$ (VI) $(0.512 \mathrm{~nm})$ and the higher electronegativity of $\mathrm{Pb}$ (II) (1.69) than Cr (VI) (5.08) Ogbu et al. (2019). These factors accounts for the higher adsorption of $\mathrm{Pb}$ (II) than other metals on adsorbents which has been reported in similar research works (Akpomie and Dawodu, 2014; Chukwuemeka-Okorie et al. (2018). It is noteworthy that the optimum adsorption at $\mathrm{pH} 3$ for $\mathrm{Cr}$ (VI) and $\mathrm{pH} 6$ for $\mathrm{Pb}$ (II) was carried out in the batch adsorption experiment to avoid the precipitation of metal ions associated with higher $\mathrm{pH}$ values. 


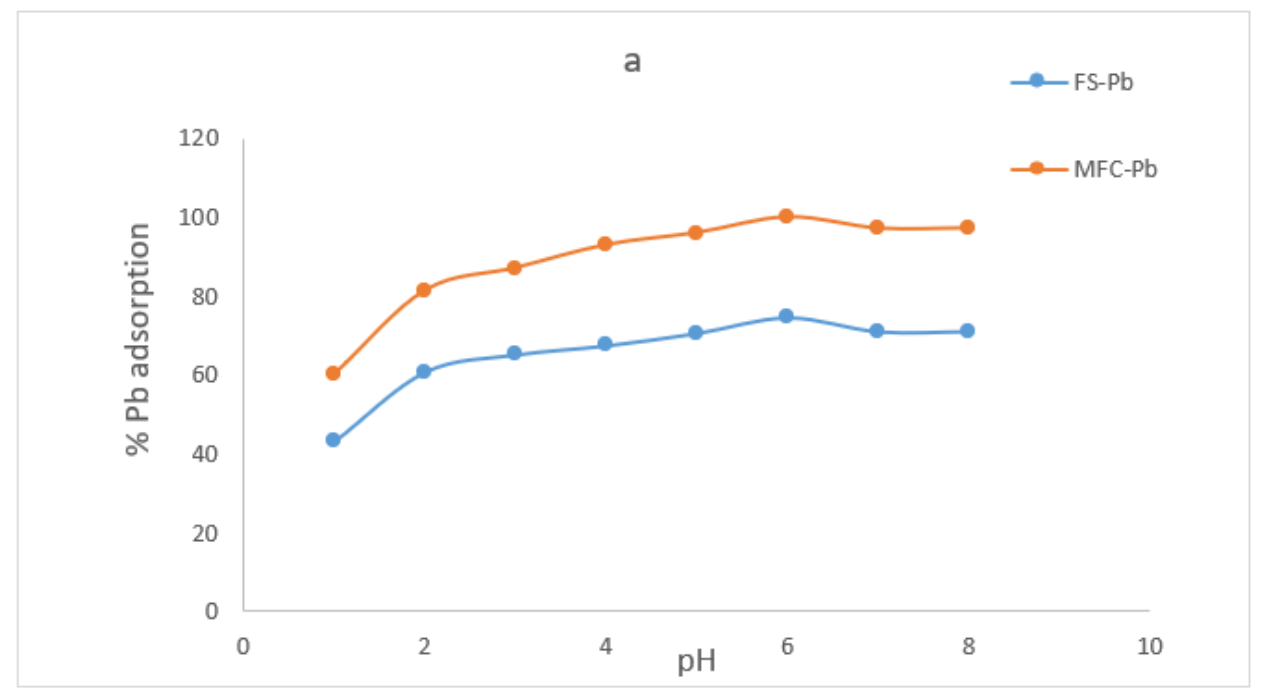

Figure 8 Effect of $\mathrm{pH}$ of solution on the percentage adsorption of $\mathrm{Pb}$ (II) ions onto FS and MFC.

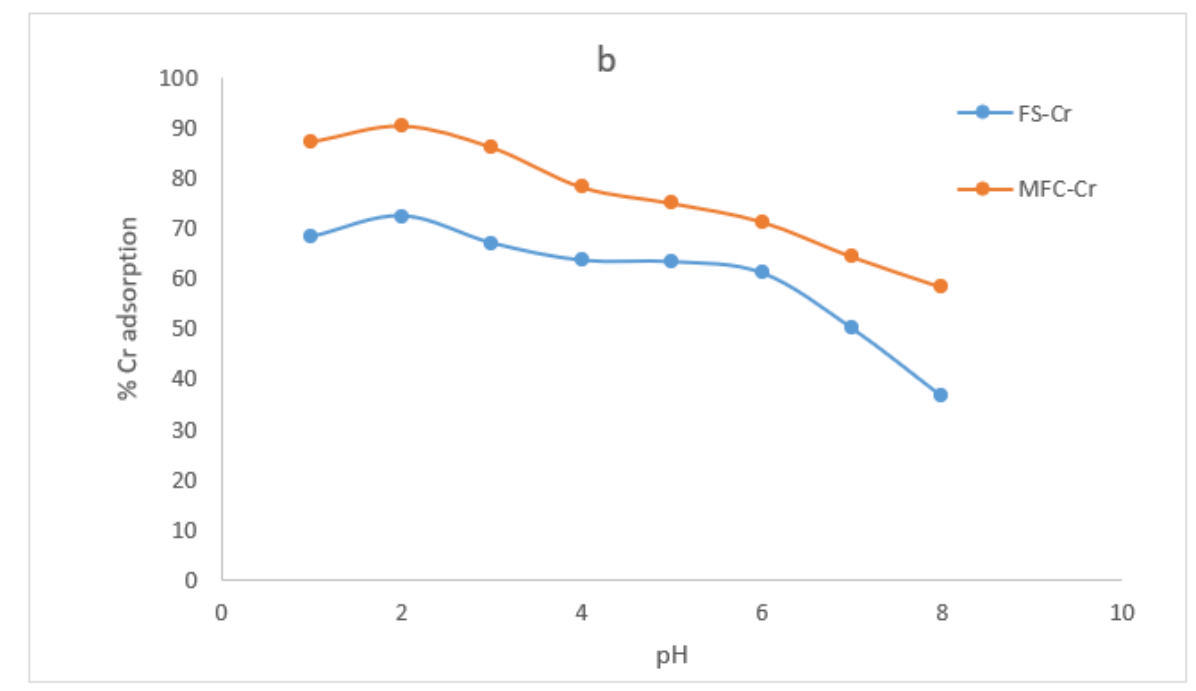

Figure 9 Effect of $\mathrm{pH}$ of solution on the percentage adsorption of $\mathrm{Cr}(\mathrm{VI})$ ions onto FS and MFC.

\subsubsection{EFFECT OF INITIAL METAL CONCENTRATION METAL ADSORPTION}

The results of the influence of initial metal concentration on the percentage adsorption of $\mathrm{Pb}$ (II) and Cd (II) on the adsorbents is shown in Figures 10 and 11.

Decrease in percentage removal of the metal ions on the adsorbents with increase in initial metal ion concentration was observed. In fact, with increase in initial metal concentration after $100 \mathrm{mg} / \mathrm{L}$, the percentage removal of $\mathrm{Pb}$ (II) decreased from 68.76 to $50.66 \%$ and 91.86 to $68.16 \%$ for FS and MFC respectively. Similarly, the percentage adsorption of $\mathrm{Cr}$ (VI) also showed a decrease from 63.86 to $32.00 \%$ (FS) and 91.48 to $60.49 \%$ (MFC) respectively. The decrease in percentage adsorption with 
increase in metal ion concentration is due to the fact that at lower concentrations, more of the metal ions would be removed by the abundant active sites on the surface of the adsorbents. However at higher metal ion concentrations, less metal ions were adsorbed due to the saturation of the available active adsorption sites on the adsorbent surface preventing further metal ion binding hence the adsorption percentages decrease Ozdes et al. (2011). This implies that if the concentration is significantly increased further, a corresponding decrease in percentage removal would be expected due to complete saturation of the active sites. Similar result has been reported (Das and Mondal, 2011).

The influence of metal concentration on the adsorption (uptake) capacity of the adsorbents for $\mathrm{Pb}$ (II) and Cd (II) was also determined as illustrated in Figures 3.2 (c and d). However, unlike the decrease observed in percentage adsorption, an increase in adsorption capacity for the ions on all the adsorbents with increase concentration was recorded. With increase in metal ion concentration from 50 to $300 \mathrm{mg} / \mathrm{L}$, an increase in the adsorption uptake capacity of $\mathrm{Pb}$ (II) from 1.335 to $2.890 \mathrm{mg} / \mathrm{g}$ and 1.817 to $3.992 \mathrm{mg} / \mathrm{g}$ and Cr (VI) from 1.216 to $2.650 \mathrm{mg} / \mathrm{g}$ and 1.730 to 3.800 $\mathrm{mg} / \mathrm{g}$ was obtained for FS and MFC respectively. The increase in uptake capacity observed might be attributed to increased concentration which generated an increase in driving force of the metal ions towards the active adsorption sites, overcoming mass transfer resistance between aqueous and solid phase Adebowale et al. (2006). Therefore, higher concentration of metal ions in solution implied that more amount of metal ion would be adsorbed per unit mass of the adsorbent with maximum utilization of the active binding sites Hossain (2013). Similar result has also been reported Chukwuemeka-Okorie et al. (2018); Ogbu et al. (2019). The adsorption of metal ions on the adsorbents at all concentrations also followed the order MFC $>$ FS adsorbent.

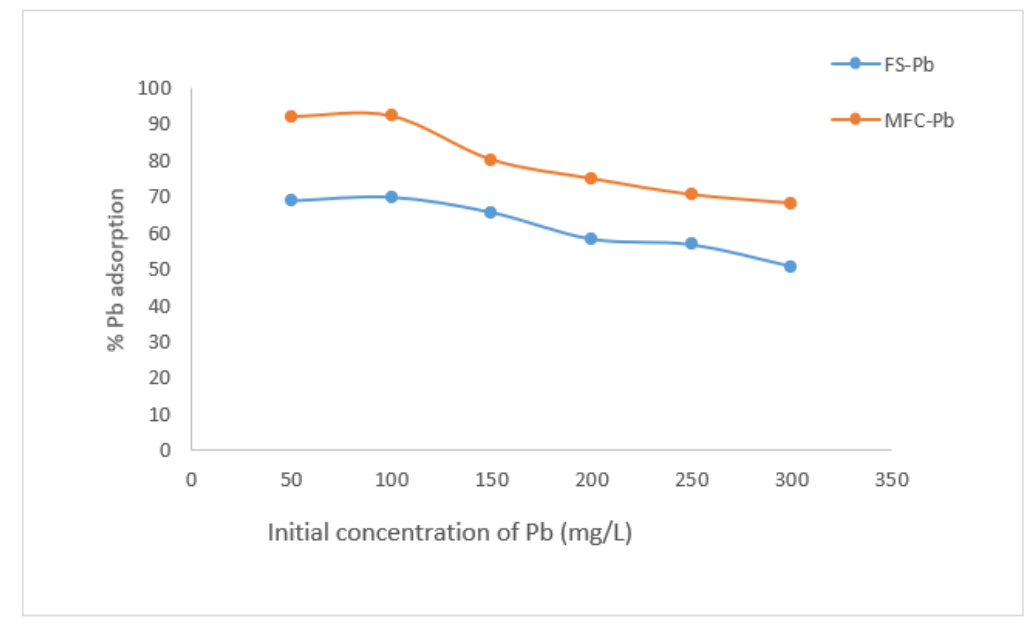

Figure 10 Effect of initial metal concentration on the adsorption of Pb (II) ions onto FS and MFC. 


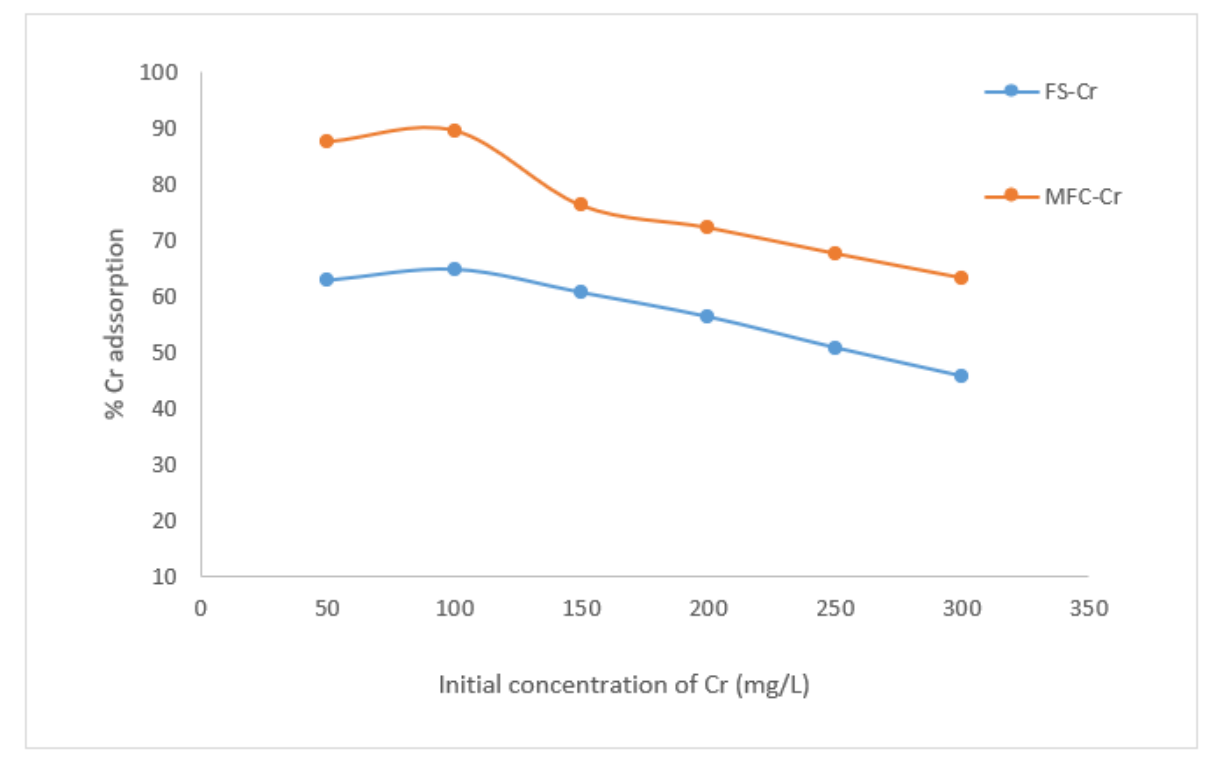

Figure 11 Effect of initial metal concentration on the adsorption of $\mathrm{Cr}(\mathrm{VI})$ ions onto FS and MFC.

\subsubsection{EFFECT OF ADSORBENT DOSAGE METAL ADSORPTION}

The effect of adsorbent dosage on removal of $\mathrm{Pb}$ (II) and Cd (II), As(III) and Cr(VI) is shown in Figures 12 and 13 respectively. An increase in the percentage adsorption of all the metal ions with increase in adsorbent dose was observed for all the adsorbents. However, the adsorbent dosage of $0.5 \mathrm{~g}$ recorded the highest adsorption because of its high adsorption capacity.

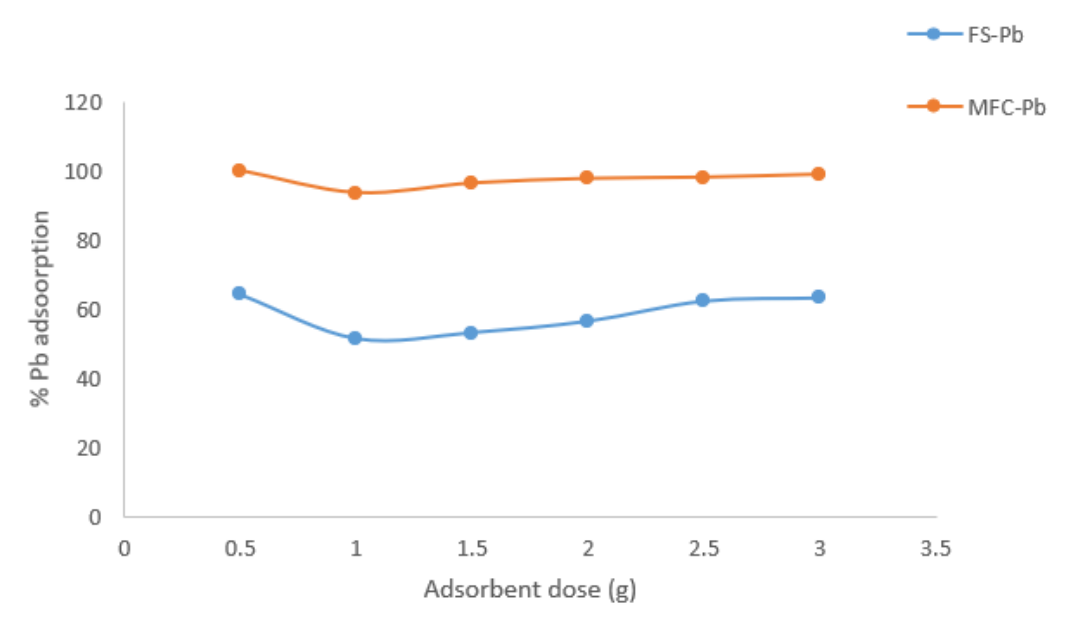

Figure 12 Effect of adsorbent dose on the percentage adsorption of Pb (II) ions onto FS and MFC. 


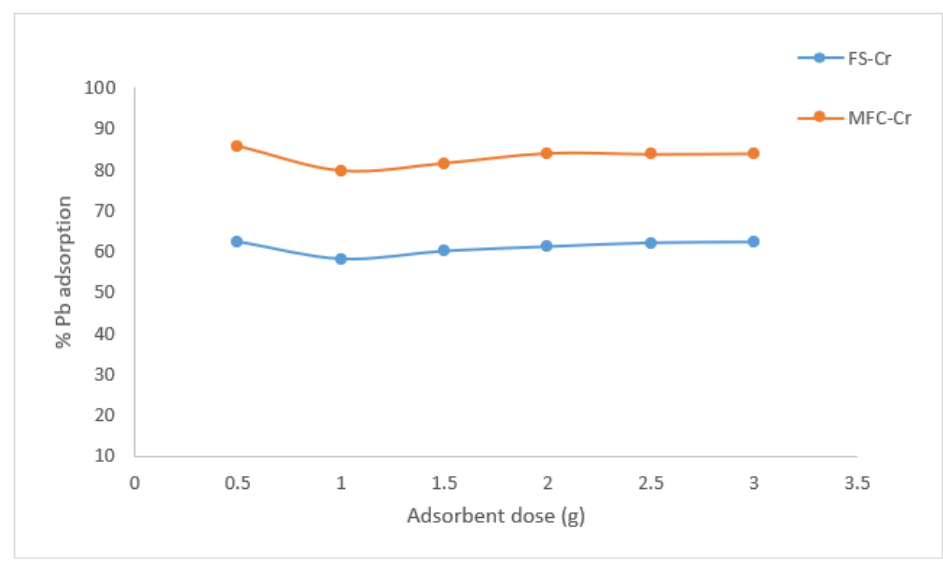

Figure 13 Effect of adsorbent dose on the percentage adsorption of Cr (VI) ions onto FS and MFC.

Figure 14 Adsorption capacityTCP, FS and MFC adsorbents for the uptake of $\mathrm{Pb}^{2+}$ ions.
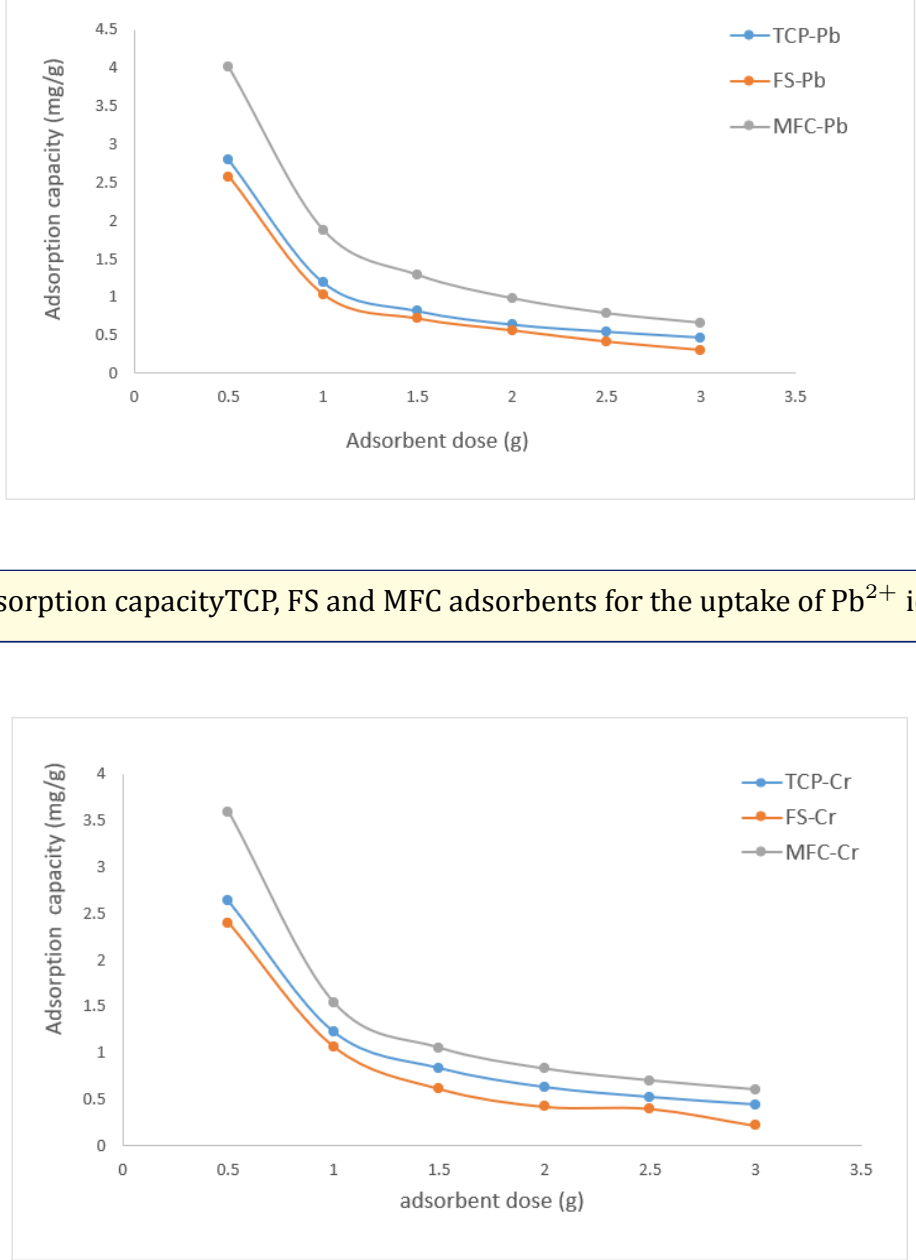

Figure 15 Adsorption capacityTCP, FS and MFC adsorbents for the uptake of $\mathrm{Cr}^{6+}$ ions. 
With adsorbent dosage from 0.50 to $3.0 \mathrm{~g}$, an increase in percentage adsorption of $\mathrm{Pb}$ (II) from 61.32 to 67.36 and 93.58 to $98.93 \%$ was obtained for FS and MFC respectively. For $\mathrm{Cr}$ (VI) ions on the respective adsorbents, an increase in removal percentage from 58.12 to $62.32 \%$ (FS) and 86.66 to $92.90 \%$ (MFC) was obtained. The increase in metal adsorption with dosage increase may be attributed to an increase in the number of active sites available on the adsorbent surface (Akpomie and Dawodu, 2014). Similar results have been reported B. Olu-Owolabi et al. (2012); Unuabonah et al. (2013); and Sanusi and Umar (2016).

However, the adsorption capacity of FS and MFC for the metal ions decreased with increase in adsorbent dosage as shown in Figure 7 ( $c$ and d). As the adsorbent dosage increased from 0.5 to $3.0 \mathrm{~g}$, the uptake capacity for $\mathrm{Pb}$ (II) ions decreased from 2.694 to $0.448,2.788$ to 0.464 , and 3.957 to $0.659 \mathrm{mg} / \mathrm{g}$ for FS and MFC respectively. Similarly, that of $\mathrm{Cr}$ (VI) showed a decrease from FS (2.493 to 0.427) and MFC (3.716 to $0.618 \mathrm{mg} / \mathrm{g}$ ) for the respective adsorbents. This decrease in equilibrium adsorption capacity may be due to the higher dosage of adsorbents, making more active sites available, as a result the adsorption sites become unsaturated (Li et al., 2011). This decrease could also be attributed to a decrease in the total surface area of the adsorbents and increase in diffusion path length resulting from overlapping or aggregation of adsorption sites Adebowale et al. (2006); Ozdes et al. (2011) and Sanusi et al., 2014). The adsorption trend of metal ions onto the adsorbents was also in the order MFC $>\mathrm{FS}$, while that for metal ions was $\mathrm{Cr}<\mathrm{Pb}$. These results clearly indicated that addition of TCP to FS and the calcination process has improved the adsorption capacity of the feldspar which is desirable in the present study. Since MFC gave a vivid higher adsorption capacity than TCP and FS, results has indicated that the use of TCP in modifying FS has produced a good composite material (MFC). Similar results on improving the adsorption capacity of a montmorillonite clay using rice husk has been reported (Akpomie and Dawodu, 2014).

\subsubsection{EFFECT OF CONTACT TIME METAL ADSORPTION}

The results of the effect of contact time on the adsorption of $\mathrm{Pb}$ (II) and $\mathrm{Cr}$ (VI) ions onto the adsorbents were presented in Figures 16 and 17. An initial rapid adsorption was observed which increased until equilibrium was reached, after then the metal uptake rate became slow steadily.

It was observed that $\mathrm{Pb}$ (II) and $\mathrm{Cr}$ (VI) ions uptake was rapid within (15-30 min), afterward it continued at a slower rate and finally reached equilibrium in 60 minutes. After equilibrium, there was little or no adsorption (marginal uptake) till 300 minutes. Further increase in contact time beyond the equilibrium time had no significant effect on the amount of $\mathrm{Pb}$ (II) and $\mathrm{Cr}$ (VI) ions adsorbed. The equilibrium percentage adsorption of $\mathrm{Pb}$ (II) ions was $80.92 \%$ (FS) and $99.72 \%$ (MFC) and that of $\mathrm{Cr}$ (VI) was $65.99 \%$ (FS) and $96.24 \%$ (MFC) at contact time of 60 min respectively. The presence of more vacant adsorption active sites at the surface of FS and MFC initially accounted for the initial rapid metal uptake, afterward the metal adsorption progressed slowly 
and finally attained equilibrium at 60 minutes when the active adsorption sites were saturated. Similar observation on the effect of contact time on the two metal uptake was reported Sanusi and Umar (2016). The faster rate of adsorption of $\mathrm{Pb}$ (II) as compared to $\mathrm{Cr}$ (VI) is due to the smaller ionic radii of $\mathrm{Pb}$ (II) $(0.097 \mathrm{~nm})$ than $\mathrm{Cr}$ (VI) $(0.12 \mathrm{~nm})$ which makes its diffusion faster to the surface of adsorbents than the larger-sized Cr (VI) ion Unuabonah et al. (2013).

From the batch adsorption study, an optimum contact time of $60 \mathrm{~min}$ for $\mathrm{Pb}$ and $\mathrm{Cr}$ ) was used in this study to ensure that accurate equilibrium adsorption of the metal ions on all the adsorbents was attained.

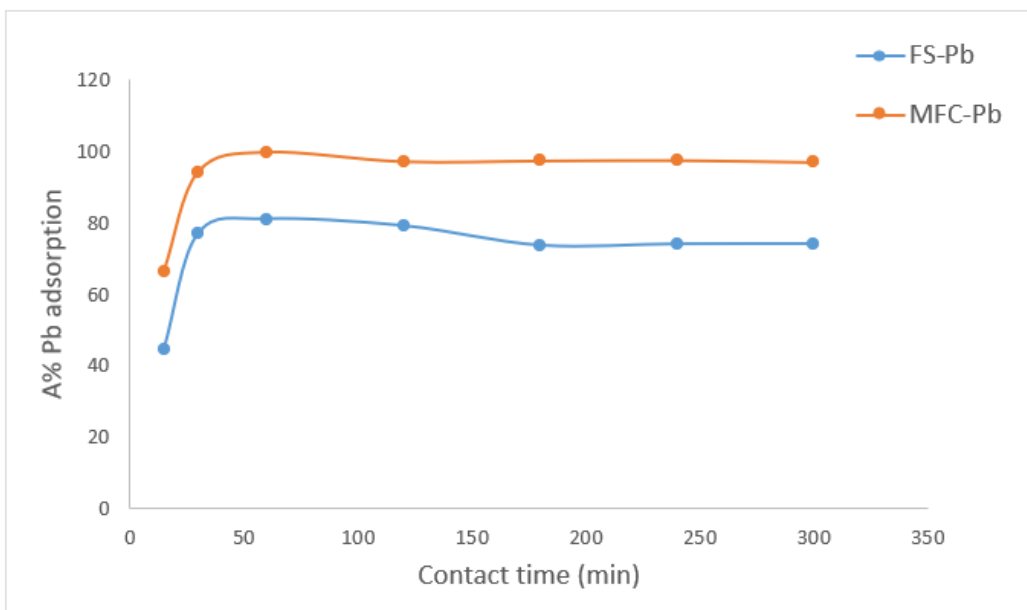

Figure 16 Effect of contact time on the percentage adsorption of $\mathrm{Pb}$ (II) ions onto FS and MFC.

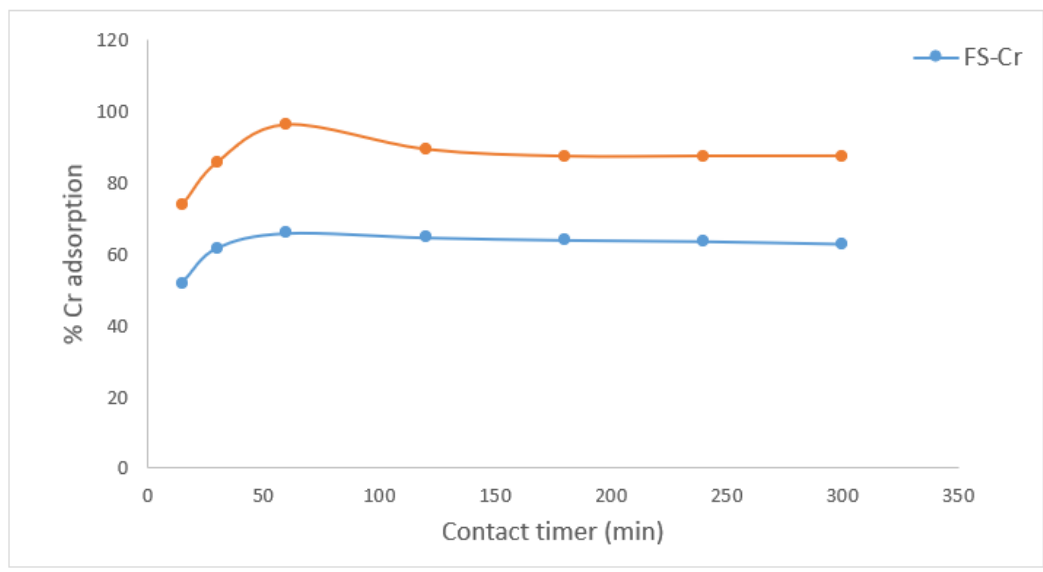

Figure 17 Effect of contact time on the percentage adsorption of $\mathrm{Cr}$ (VI) ions onto FS and MFC. 


\subsection{MODEL DEVELOPMENT FOR OPTIMIZATION OF PB (II AND CR (VI ADSORPTION}

In this experimental study, the central composite design (CCD) method was applied to design experiments as presented in Table 5 , propose empirical models, investigate the interaction effects of four factors (adsorption parameters) and determine the optimum values for the studied operating variables $(\mathrm{pH}$, initial metal concentration, adsorbent dose and contact time) to achieve the maximum response (adsorption efficiency of $\mathrm{Pb}$ (II) and $\mathrm{Cr}$ (VI) in aqueous solution (Yazdani et al., 2013; Singh and Bhateria (2020).

The models (in actual form) for the respective metal ion uptake as presented in equations 2 and 3 were employed to analyze the effect of the independent variables on adsorption amount $(Y$. The results revealed that $\mathrm{pH}$, adsorbent dosage, contact time and metal concentration presented the most significant effects on the metal adsorption. A positive sign coefficient term indicating the variables affecting metal uptake positively (synergetic effect) while negative sign coefficient terms are suggestive of uptake been antagonistic effect (decrease) on response values predicted by the quadratic model equations (Yazdani et al., 2013).

$\mathrm{Pb}$ (II) Removal \%

$$
\begin{aligned}
Y_{1} & =59.67-19 C_{O}+1.4 T+17.76 D+3.8 p H C_{O}-3.88 C O D-2.45 T D+1.71 C_{O}^{2} \\
& +7.7 C_{O}^{2} T-13.43 C O^{2} p H+15.25 C O^{2} D
\end{aligned}
$$

$\mathrm{Cr}$ (VI) Removal \%

$$
\begin{aligned}
& Y_{4}=17.89+0.43 C_{o}+1.04 C_{o}^{2}+0.23 D-0.83 D^{2}-2.25 p H+3.18 p H^{2} \\
& \quad-1.25 T+0.18 T^{2}+1.06 C o D-0.58 C o p H-0.37 C o T \\
& \quad+0.29 D p H+0.045 D T+0.97 p H T
\end{aligned}
$$

Table 5 Experimental design for adsorption of Pb (II) and Cr (VI) on MFC using central composite design (CCD).

\begin{tabular}{lllllll}
\hline $\begin{array}{l}\text { Run } \\
\text { order }\end{array}$ & $\begin{array}{l}\text { Adsorption } \\
\text { Parame- } \\
\text { ters }\end{array}$ & & & Responses & CCD \\
Position
\end{tabular}




\begin{tabular}{|c|c|c|c|c|c|c|c|}
\hline \multicolumn{8}{|c|}{ Table 5 continued } \\
\hline 5 & 5 & 300 & 1.5 & 210 & 86.25 & 45.48 & Factorial \\
\hline 6 & 5 & 100 & 0.5 & 60 & 80.00 & 61.37 & Central \\
\hline 7 & 5 & 100 & 0.5 & 120 & 85.65 & 75.09 & Central \\
\hline 8 & 5 & 100 & 0.5 & 120 & 79.98 & 80.05 & Central \\
\hline 9 & 6 & 100 & 0.5 & 60 & 90.89 & 66.89 & Central \\
\hline 10 & 6 & 100 & 1.0 & 180 & 78.66 & 79.56 & Axial \\
\hline 11 & 8 & 100 & 1.0 & 210 & 92.55 & 77.75 & Axial \\
\hline 12 & 5 & 50 & 0.5 & 30 & 85.02 & 55.84 & Axial \\
\hline 13 & 5 & 300 & 0.5 & 30 & 74.66 & 60.11 & Factorial \\
\hline 14 & 5 & 200 & 2.5 & 30 & 90.75 & 71.63 & Axial \\
\hline 15 & 5 & 150 & 2.0 & 60 & 69.80 & 78.39 & Factorial \\
\hline 16 & 5 & 100 & 2.5 & 180 & 72.03 & 45.88 & Factorial \\
\hline 17 & 2 & 100 & 1.5 & 120 & 71.98 & 83.14 & Factorial \\
\hline 18 & 2 & 100 & 0.5 & 60 & 76.25 & 88.48 & Central \\
\hline 19 & 2 & 100 & 0.5 & 60 & 60.00 & 81.37 & Central \\
\hline 20 & 2 & 100 & 0.5 & 60 & 68.65 & 85.09 & Central \\
\hline 21 & 2 & 100 & 2.5 & 120 & 69.58 & 80.05 & Factorial \\
\hline 22 & 3 & 100 & 2.0 & 60 & 80.29 & 66.89 & Factorial \\
\hline 23 & 5 & 100 & 0.5 & 120 & 88.66 & 79.56 & Factorial \\
\hline 24 & 5 & 50 & 1.0 & 180 & 92.55 & 77.75 & central \\
\hline 25 & 6 & 100 & 0.5 & 120 & 95.02 & 55.84 & Axial \\
\hline 26 & 6 & 100 & 0.5 & 120 & 74.66 & 60.11 & Factorial \\
\hline 27 & 6 & 100 & 0.5 & 180 & 90.75 & 71.63 & Axial \\
\hline 28 & 3 & 150 & 2.5 & 30 & 79.80 & 80.39 & Factorial \\
\hline 29 & 3 & 100 & 1.0 & 60 & 90.03 & 75.88 & Factorial \\
\hline 30 & 5 & 100 & 1.5 & 60 & 91.98 & 69.14 & Factorial \\
\hline 31 & 8 & 100 & 0.5 & 30 & 96.25 & 58.48 & Factorial \\
\hline 32 & 6 & 200 & 2.0 & 210 & 94.00 & 61.37 & Axial \\
\hline
\end{tabular}

The results of the statistical analysis and significance test for the model applied were obtained from analysis of variance (ANOVA) as displayed in Tables 6 and 7 . A higher $F$ value indicates a greater significance of most of the variables in the response indicated in model regression equations. Most of the probability ( $p$ values) of the models are less than 0.05 which indicated that they are statistically significant (s) while those greater than 0.05 are insignificant (n) indicated as superscript on the values shown in Table 6, 7. Those significant values were further confirmed by the high $\mathrm{R}^{2}$ of the models Adetokun et al. (2019). The optimum variables predicted by the model and that of experimental results for maximum uptake of the four metals were presented in Tables 8 and 9 . These were further validated by comparing experimental results to the predicted results. Higher coefficients of determination i.e. adjusted $R^{2}$ (0.9919-0.9986), is in good agreement with the predicted $R^{2}(0.9966-0.9996)$ as shown in table 8, 9 signifying less variation between the predicted and actual values Adetokun et al. (2019). The results confirmed the adequacy of the selected quadratic model Singh and Bhateria (2020). 


\subsection{VALIDATION OF THE MODELS FOR OPTIMIZATION}

The model validation was carried out through performing four experiment sets with different combinations of the process variables and the response values $(Y, \mathrm{mg} / \mathrm{g})$ were determined using the coded values of the process variables as shown in (Table 1 ) above. A good correlation of determinations $\left(R^{2} \geq 0.99\right)$ from the response plot of the predicted results against experimental (actual) results of the response factors as shown in (Figure 9a, c, e and g) and the good agreement between the $Y_{\text {pred }}$ and $Y_{\text {exp }}$ values as shown in (Tables 10 and 11 ) have demonstrated the adequacy of the models applied to predict the response results and hence the model validation in the optimization process Adetokun et al. (2019). The model summary statistics and adequacy test results are summarized in Tables 6 and 7 . The lack of fit of the model was found to be insignificant for the selected metal ions adsorption onto the adsorbent. Hence, the effect of interactions of independent adsorption variables on the responses are adequately described by the quadratic regression equation models for $\mathrm{Pb}(\mathrm{II})$ and $\mathrm{Cr}(\mathrm{VI})$ with $\mathrm{R}^{2}>0.99$. The standard deviation of the residuals were found to be 4.89 and 2.96 with small pure errors for $\mathrm{Pb}$ (III) and $\mathrm{Cr}$ (VI) ions respectively. The "adeq precision" of the model were 22.85 and 42.58 at (adeq $>4$ ) for Pb (III) and $\mathrm{Cr}(\mathrm{VI})$ ions respectively. The results showed that the value of noise ratio of the model are in the desirable range (0.987). Similar statistical results for optimization of metal adsorption was reported in a research work by Singh and Bhateria (2020).

Table 6 Analysis of variance (ANOVA) for Pb (II) and Cr (VI) adsorption models.

\begin{tabular}{|c|c|c|c|c|c|c|c|}
\hline Respon & Source & $\begin{array}{l}\text { Sum of } \\
\text { Squares }\end{array}$ & df & $\begin{array}{l}\text { Mean } \\
\text { Square }\end{array}$ & $\begin{array}{l}\text { F- } \\
\text { value }\end{array}$ & $\begin{array}{l}\text { P- value } \\
\text { Prob }>\text { F }\end{array}$ & Comments \\
\hline \multirow{11}{*}{$\begin{array}{l}\mathrm{Pb}(\mathrm{II}) \\
\text { removal }\end{array}$} & Model & 3688.33 & 9 & 1054.26 & 147.01 & $<0.0001$ & $\mathrm{SD}=4.89$ \\
\hline & $\begin{array}{l}\text { Initial } \\
\text { conc. } \\
\left(C_{0}\right)\end{array}$ & 1625.30 & 1 & 5775.00 & 241.06 & $<0.0001^{s}$ & $\begin{array}{l}\text { Mean } \\
61.92\end{array}$ \\
\hline & Time (T) & 15.72 & 1 & 15.72 & 0.66 & 0.4389 & $\mathrm{CV}=7.90$ \\
\hline & $\begin{array}{l}\text { Dosage } \\
\text { (D) }\end{array}$ & 2528.95 & 1 & 2523.21 & 105.33 & $<0.0001^{S}$ & $\begin{array}{l}\mathrm{R}_{\text {pred }}^{2} \\
0.9996\end{array}$ \\
\hline & D-pH & 305.34 & 1 & 305.34 & 25.67 & $<0.0001^{s}$ & $\begin{array}{l}\mathrm{R}_{(a d j)} \\
0.9986\end{array}$ \\
\hline & $\mathrm{C}_{0} \mathrm{~T}$ & 399.75 & 1 & 115.73 & 33.62 & 0.0555 & $\mathrm{AP}=22.85$ \\
\hline & $\mathrm{C}_{0} \mathrm{D}$ & 129.86 & 1 & 129.14 & 8.01 & 0.0045 & \\
\hline & TD & 48.13 & 1 & 48.13 & 2.01 & $0.1900^{n}$ & \\
\hline & $\mathrm{C}_{0}^{2}$ & 97.75 & 5 & 77.75 & 3.25 & 0.1051 & \\
\hline & $\mathrm{C}_{0}{ }^{2} \mathrm{~T}$ & 397.28 & 1 & 237.28 & 9.90 & $0.0118^{s}$ & \\
\hline & $\mathrm{C}_{0}^{2} \mathrm{D}$ & 721.92 & 1 & 721.92 & 30.13 & $0.0004^{s}$ & $\mathrm{R}^{2}=0.9998$ \\
\hline
\end{tabular}




\begin{tabular}{|c|c|c|c|c|c|c|}
\hline \multicolumn{7}{|l|}{ Table 6 continued } \\
\hline Residual & 25.71 & 2520 & $1.03 \quad 1.21$ & 4.30 & 0.5630 & Not signifi- \\
\hline $\begin{array}{l}\text { Lack of } \\
\text { fit Pure } \\
\text { error Cor } \\
\text { total }\end{array}$ & $\begin{array}{l}24.291 .41 \\
3823.45\end{array}$ & 545 & 0.2825 & & & cant \\
\hline
\end{tabular}

\begin{tabular}{|c|c|c|c|c|c|c|c|}
\hline \multicolumn{8}{|l|}{ Table 7} \\
\hline $\begin{array}{l}7 \\
\text { Responsı }\end{array}$ & Source & $\begin{array}{l}\text { Sum of } \\
\text { Squares }\end{array}$ & df & $\begin{array}{l}\text { Mean } \\
\text { Square }\end{array}$ & $\begin{array}{l}\text { F } \\
\text { value }\end{array}$ & $\begin{array}{l}\text { P- value } \\
\text { Prob }>\text { F }\end{array}$ & Comments \\
\hline $\mathrm{Cr}(\mathrm{VI})$ & Model & 5308.33 & 12 & 1481.76 & 321.04 & $<0.0001^{S}$ & $S D=2.96$ \\
\hline \multirow[t]{11}{*}{ Removal } & $\begin{array}{l}\text { Initial } \\
\text { conc. }\left(\mathrm{C}_{0}\right)\end{array}$ & 2545.80 & 1 & 2545.80 & 241.06 & $<0.0001^{S}$ & $\begin{array}{l}\text { Mean } \\
23.92\end{array}$ \\
\hline & Time (T) & 60.00 & 1 & 60.00 & 1.45 & 0.4389 & $\mathrm{CV}=5.90$ \\
\hline & $\begin{array}{l}\text { Dosage } \\
\text { (D) }\end{array}$ & 2258.95 & 1 & 2258.95 & 190.01 & $<0.0001$ & $\begin{array}{l}\mathrm{R}_{\text {pred }}^{2} \\
0.9966\end{array}$ \\
\hline & D-pH & 1225.34 & 1 & 1225.34 & 98.12 & $<0.0001$ & $\begin{array}{l}\mathrm{R}^{2}(a d j) \\
0.9919\end{array}$ \\
\hline & $\mathrm{C}_{0} \mathrm{~T}$ & 399.75 & 1 & 399.75 & 33.62 & 0.0555 & $\mathrm{AP}=42.58$ \\
\hline & $\mathrm{C}_{0} \mathrm{D}$ & 120.14 & 1 & 120.14 & 5.01 & $0.0519^{n}$ & \\
\hline & TD & 99.00 & 1 & 99.00 & 8.33 & 0.0068 & \\
\hline & $\mathrm{C}_{0}{ }^{2}$ & 379.07 & 1 & 379.07 & 3.25 & 0.1051 & \\
\hline & $\mathrm{C}_{0}{ }^{2} \mathrm{~T}$ & 237.28 & 1 & 237.28 & 9.90 & 0.0118 & \\
\hline & $\mathrm{C}_{0}^{2} \mathrm{D}$ & 721.92 & 1 & 721.92 & 30.13 & $<0.0001^{S}$ & \\
\hline & $\begin{array}{l}\text { Residual } \\
\text { Lack of } \\
\text { fit Pure } \\
\text { error Cor. } \\
\text { total }\end{array}$ & $\begin{array}{l}181.22 \\
157.16 \\
8.40 \\
5416.25\end{array}$ & $\begin{array}{lll}25 & 21 & 5 \\
26 & & \end{array}$ & $\begin{array}{l}7.36 \\
8.12 \\
1.68\end{array}$ & 1.51 & 0.3561 & $\mathrm{R}^{2}=0.9916$ \\
\hline
\end{tabular}

S: significant; $n$ : insignificant; df: degree of freedom; SD: standard deviation; CV: coefficient of variance; $\mathrm{R}^{2}$ : correlation of determination; AP: adequate precision.

\subsection{RESPONSE SURFACE PLOTTING}

Three-dimensional surface plots presented the individual and interactive effects of independent variables, namely, $\mathrm{pH}$, initial metal concentration, contact time and adsorbent dosage on the adsorption efficiencies and capacities of $\mathrm{Pb}$ (II) and $\mathrm{Cr}$ (VI) i.e. the response values as predicted by the models. The combined effect of interaction of initial metal concentration and adsorbent dosage shown in Figures (8 and 10) indicated the significant influence of both factors on the adsorptive behaviour of $\mathrm{Pb}$ (II) and Cr (VI) onto MFC adsorbent. For all the metal ions, while the removal percentage increased with increasing adsorbent dosage, this was due to the presence of more active adsorption sites and large adsorbent surface area that is readily available for metal uptake Adetokun et al. (2019); Sanusi and Umar (2016). On the contrary, the removal percentage was reduced by increasing the initial metal concentration. This observation might be due to the limited active sites on the adsorbent surface 
which become saturated at high adsorbate concentrations (Ozde et al., 2011). More so, the removal of metal ions onto MFS was increased as the contact time increased from (30 to $60 \mathrm{~min}$ ) for of $\mathrm{Pb}(\mathrm{II})$ and $\mathrm{Cr}(\mathrm{VI})$. These results confirmed that the initial metal adsorption rate was very rapid due to the availability of large surface area and the presence of unused sites on the adsorbent surface Ogbu et al. (2019). The slow rate of metal ion removal after equilibrium time might be due to the difficulty of the metal ions in reaching the remaining vacant adsorbent active sites, a resultant of barrier factor i.e. repulsive forces (Akpomie and Dawodu, 2014). As seen in Figures 6 and 7 he response surface diagram for the interactive effect of the adsorbent dosage, initial metal concentration and the initial $\mathrm{pH}$ showed that the metal adsorption by the MFC extremely depends on the $\mathrm{pH}$ of the solution. $\mathrm{Pb}$ (II) removal at lower $\mathrm{pH}$ is lower than the metal removal at higher $\mathrm{pH}$ in the experimental $\mathrm{pH}$ range. As has already been mentioned, at the lower $\mathrm{pH}$, there are great number of protons in the aqueous solution which compete with the metal ions. Conversely, at the higher $\mathrm{pH}$, there are a considerable number of $\mathrm{OH}^{-}$in the aqueous medium which enhanced metal adsorption. Therefore, the adsorbent can provide more negative charges in very low acidic or alkaline medium rather than at higher acidic medium, and since the metal ions are cationic in nature, removing them from the alkaline solution would be much easier. In addition, it could be seen that the change of adsorbent dose and initial metal concentration do have a significant interactive effect on metal removal efficiency and capacities even at different $\mathrm{pH}(2,5$ and 6).

The optimum values of experimental (actual) and the maximum values predicted responses are presented in Tables 8 and 9 . The maximum removal percentages for $\mathrm{Pb}$ (II) and Cr (VI) were predicted to be $99.95 \%$ and $92.48 \%$, respectively. Verification experiments were conducted under the optimum conditions, and the removal percentages were $99.98 \%$ and $96.24 \%$ for $\mathrm{Pb}$ (II) and $\mathrm{Cr}$ (VI) respectively at adsorbent dose of $1 \mathrm{~g}$, initial metal concentration $(100 \mathrm{mg} / \mathrm{L})$ and temperature $\left(300^{\circ} \mathrm{K}\right)$. These experimental results were similar to the predicted values and indicated the suitability, accuracy and adequacy of the models used. The metal uptake capacities for the metals obtained under the optimum experimental conditions were 14.148 $\mathrm{mg} / \mathrm{g}$ and $3.504 \mathrm{mg} / \mathrm{g}$ for $\mathrm{Pb}$ (II) and $\mathrm{Cr}$ (VI) respectively while the predicted values for $\mathrm{Pb}$ (II) and $\mathrm{Cr}$ (VI) were $14.021 \mathrm{mg} / \mathrm{g}$ and $3.428 \mathrm{mg} / \mathrm{g}$ respectively.

\subsection{PROCESS OPTIMIZATION}

The main objective of the present work was to reach the most effective values of process variables for the optimization of $\mathrm{Pb}$ (II) and $\mathrm{Cr}$ (VI) adsorption onto the MFC composite from aqueous solution. This aim was fulfilled using the quadratic model within the studied experimental range of the selected parameters. The optimization of the selected adsorption parameters at optimum values of $\mathrm{pH}$ ( 2 and 6 ), temperature $300^{\circ} \mathrm{K}$, initial metal concentration $100 \mathrm{mg} / \mathrm{L}$, and adsorbent dose $0.5 \mathrm{~g}$ revealed the maximum metal uptake capacities (predicted values) of $14.021 \mathrm{mg} / \mathrm{g}$ and 3.128 $\mathrm{mg} / \mathrm{g}$ for $\mathrm{Pb}(\mathrm{II})$ and $\mathrm{Cr}(\mathrm{VI})$ respectively. Correspondingly, the experimental values of 
the metal adsorption under the optimum condition of the process parameters were obtained as $(14.148 \mathrm{mg} / \mathrm{g}$ and $3.504 \mathrm{mg} / \mathrm{g}$ ) for the selected metal ions (Table 8). It should be noted that the experimental and predicted results of metal adsorption efficiency onto MFC at optimum variables values was determined as $(99.98 \%, 99.95 \%)$ for $\mathrm{Pb}$ (II) and 96.24\%, 92.48\%) for $\mathrm{Cr}$ (VI) respectively as shown in (Table 9 ).

Table 8 The model validation results for predicted and experimental maximum values of $\mathrm{Pb}$ (II) and $\mathrm{Cr}$ (VI) adsorption capacity onto MFC obtained in optimum conditions.

\begin{tabular}{|c|c|c|c|c|c|c|c|c|}
\hline $\begin{array}{l}\text { Exp. } \\
\text { No }\end{array}$ & $\mathbf{p H}$ & $\begin{array}{l}\text { Time } \\
\text { (T) }\end{array}$ & $\begin{array}{l}\text { Dose } \\
\text { (g) }\end{array}$ & $\begin{array}{l}\quad \text { Metal } \\
\text { conc. } \\
\text { (mg/L) }\end{array}$ & $\begin{array}{l}\text { Adjuste } \\
\mathbf{R}^{2}\end{array}$ & $\begin{array}{l}\begin{array}{r}\text { Pre- } \\
\text { dicted }\end{array} \\
\mathbf{R}^{2}\end{array}$ & $\begin{array}{l}\text { Metal conc. } \\
(\mathrm{mg} / \mathrm{L})\end{array}$ & $\begin{array}{l}\text { Adsorption } \\
\text { capacity }(\mathrm{mg} / \mathrm{g})\end{array}$ \\
\hline & & & & & & & & Exp. Pred. \\
\hline $\begin{array}{l}\mathrm{Pb} \\
\text { (II) }\end{array}$ & 6 & 60 & 0.5 & 100 & 0.9986 & 0.9996 & 100 & 14.14814 .021 \\
\hline $\begin{array}{l}\mathrm{Cr} \\
(\mathrm{VI})\end{array}$ & 2 & 60 & 0.5 & 100 & 0.9919 & 0.9966 & 100 & 3.5043 .428 \\
\hline
\end{tabular}

Table 9 The model validation results for predicted and experimental maximum values of $\mathrm{Pb}(\mathrm{II})$ and $\mathrm{Cr}(\mathrm{VI})$ removal percentages obtained in optimum conditions.

\begin{tabular}{|c|c|c|c|c|c|c|c|c|c|}
\hline \multirow[t]{2}{*}{$\begin{array}{l}\text { Heavy } \\
\text { Metal }\end{array}$} & \multirow[t]{2}{*}{ pH } & \multirow[t]{2}{*}{$\begin{array}{l}\text { Time } \\
(\mathrm{min})\end{array}$} & \multirow[t]{2}{*}{$\begin{array}{l}\text { Dose } \\
\text { (g) }\end{array}$} & \multirow[t]{2}{*}{$\begin{array}{l}\text { Metal } \\
\text { conc. } \\
\text { (mg/L) }\end{array}$} & \multirow[t]{2}{*}{$\begin{array}{l}\text { Adjustt } \\
\mathbf{R}^{2}\end{array}$} & \multirow[t]{2}{*}{$\mathbf{R}^{2}$ Predicted } & \multicolumn{2}{|c|}{ Adsorption (\%) } & Model \\
\hline & & & & & & & Exp. & Pred. & $\begin{array}{l}\text { Desir- } \\
\text { ability }\end{array}$ \\
\hline $\mathrm{Pb}(\mathrm{II})$ & 6 & 60 & 0.5 & 100 & 0.9986 & 0.9996 & 99.98 & 99.95 & 0.987 \\
\hline $\mathrm{Cr}(\mathrm{VI})$ & 2 & 60 & 0.5 & 100 & 0.9919 & 0.9966 & 96.24 & 92.48 & 0.987 \\
\hline
\end{tabular}

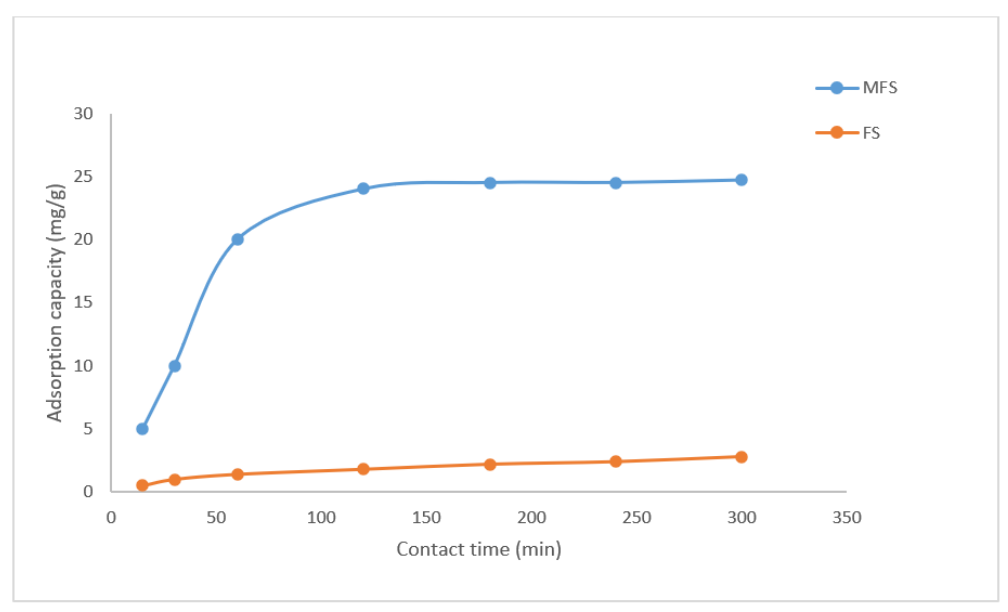

Figure 18 Comparison of effect of contact time on adsorption capacities of metal ions on FS and MFC in optimum experimental conditions. 
Comparing the potential of the bio-based composite adsorbent (MFC) for the uptake rate of the selected metal ions with pure feldspar (FS), it is evident from Figure 18 that the adsorption amount of metal ions onto FS lower than the adsorption amount of metal ions onto the MFC. This result has indicated that the metal ions have lower affinity to feldspar surface, while its modification with Theobroma cacao pods resulted the enhancement of metal ions adsorption onto the composite material (MFC). Similar observations were reported in the previous research works on optimization of adsorption process parameters (Yazdani et al., 2013; Adetokun et al. (2019).

\subsection{ADSORPTION ISOTHERM STUDIES}

The equilibrium adsorption isotherms are one of the most important data that provide information on surface properties of adsorbents, adsorption mechanism and sorbents affinity (Das and Mondal, 2011). The relationship between the amount of $\mathrm{Pb}$ (II) and $\mathrm{Cr}$ (VI) ions adsorbed onto the adsorbents (FS and MFC) and their equilibrium concentrations in aqueous solution were evaluated using of Langmuir and Freundlich models.

Table 10 Adsorption Isotherm Parameters Pb (II) and Cr (VI) adsorption onto FS and MFC.

\begin{tabular}{lllll}
\hline Metal & Pb (II) & \multicolumn{3}{l}{ Cr (VI) } \\
Isotherm/ Adsorbent & FC & MFC & FC & MFC \\
\hline Langmuir & & & & \\
$\mathrm{q}_{m}(\mathrm{mg} / \mathrm{g})$ & 60.48 & 98.66 & 56.74 & 88.49 \\
$\mathrm{~b}\left(\mathrm{~L} / \mathrm{mg}^{-1}\right)$ & 0.024 & 0.068 & 0.009 & 0.001 \\
$\mathrm{R}_{L}$ & 0.294 & 0.128 & 0.531 & 0.910 \\
$\mathrm{R}^{2}$ & 0.9965 & 0.9999 & 0.8862 & 0.9032 \\
Freundlich & & & & \\
$\mathrm{K}_{F}$ & 10.97 & 39.03 & 1.171 & 0.069 \\
$\mathrm{n}$ & 1.01 & 1.35 & 2.36 & 3.22 \\
\hline $\mathrm{R}^{2}$ & 0.8366 & 0.9358 & 0.9977 & 0.9997 \\
\hline
\end{tabular}

The equilibrium data obtained from the adsorption of $\mathrm{Pb}(\mathrm{II})$ and $\mathrm{Cr}(\mathrm{VI})$ ions onto FS and MFC were fitted the Langmuir and Freundlich isotherm models (Fig. 10(a) and (b)). All of the isotherm constants and correlation coefficients were calculated from the linear equations of the models and provided in Table 8. According to the Langmuir isotherm model, the maximum monolayer adsorption capacity of FS and MFS for $\mathrm{Pb}$ (II) was found to be higher than for $\mathrm{Cr}$ (VI) ions indicating that $\mathrm{Pb}$ (II) ions were well adsorbed onto adsorbents surfaces than Cd (II) ions. Between 50 and $300 \mathrm{mgL}^{-1}$ of initial metal ions concentration, the $\mathrm{R}_{L}$ values ranged from 0.76 to 0.11 for $\mathrm{Cr}$ (VI) ions and from 0.22 to 0.01 for $\mathrm{Pb}$ (II) ions then approached zero with increase in the $\mathrm{C}_{o}$ values of both metal ions, indicated that the $\mathrm{Pb}$ (II) and $\mathrm{Cr}$ (VI) adsorption onto FS and MFS is favorable under studied conditions. Furthermore n values, obtained from 
Freundlich isotherm model were higher than unity which supported the favorability of adsorption process. By comparing the correlation coefficient values obtained from Langmuir and Freundlich isotherm models, it could be concluded that the Langmuir isotherm model is more suitable for $\mathrm{Pb}$ (II) ions while the experimental data obtained for $\mathrm{Cr}$ (II) ions adsorption were fitted well to Freundlich isotherm model. This may be due to both homogeneous and heterogeneous distribution of adsorption active sites on the surface of the FS and MFC. Similar observation was reported Adebowale et al. (2006); Ozdes et al. (2011); Unuabonah et al. (2013)

\subsection{ADSORPTION KINETIC STUDIES}

Kinetic modeling evaluates adsorption mechanism, which include mass transfer, chemical reaction and diffusion control (Ogbu et al., 2018). Four adsorption kinetics models were employed to investigate the mechanism and rate of the adsorption process. These are the Lagergren pseudo-first-order (PFO), pseudo second-order (PSO), intra-particle diffusion and Elovich models. The kinetic rate constants obtained from the application of the kinetic model equation for the adsorption of $\mathrm{Pb}$ (II) and $\mathrm{Cr}$ (VI) ions unto the adsorbents are shown in Table 9.

The metal ions uptake was rapid for the first 30 min because at the beginning of the adsorption the active adsorption sites on the adsorbent surface were more available thus metal ions could interact easily with these sites. Afterward it continued at a slower rate and finally reached to the equilibrium by virtue of the saturation of adsorption sites on adsorbent surface within $60 \mathrm{~min}$.

The $\mathrm{q}_{e}$ and rate constants were calculated from the slope and intercept of the plots of $\log \left(\mathrm{q}_{e}-\mathrm{q}_{t}\right)$ vs. $\mathrm{t}$; and $\mathrm{t} / \mathrm{q}$ vs. $\mathrm{t}$ for PFO and PSO respectively.

From equation 10, a plot of and interceptadsorption mechanism is in line with the intra-particle diffusion process. The intra-particle diffusion process, though not the only rate-limiting steis the predominant in the metal adsorption onto FS and MFC, as the plot did not pass through the origin B. I. Olu-Owolabi et al. (2016) , Sanusi and Umar (2016) .Furthermore, the occurrence of the intercept C, showed the involvement of surface active sites onad(Yazdaniet al2013A significant adsorption of both $\mathrm{Pb}$ (II) and $\mathrm{Cr}$ (VI) ions was achieved during movement of adsorbates from solution to adsorbents surface indicating the conformity of metal uptake process to the IP Chukwuemeka-Okorie et al. (2018).

By evaluating the intra-particle mass transfer curve, it was observed that the $\mathrm{Pb}$ (II) and Cr (VI) adsorption process was found to be followed by two distinct phases. The first phase is attributed to the diffusion of metal ions through the solution to the external surface of FS and MFS while the second phase indicated the intra-particle diffusion (IPD) of $\mathrm{Pb}$ (II) and $\mathrm{Cr}$ (VI) ions into the pores of the adsorbents. The intraparticle rate constants for the first phase $\left(\mathrm{k}_{i d}, 1\right)$ and second phase $\left(\mathrm{k}_{i d}, 2\right)$ and $\mathrm{C}$ parameters were obtained from the plot of qt versus ${ }^{t 1 / 2}$ and the results were given in Table 11 . By comparing the rate constants, the lower values of $\left(\mathrm{k}_{i d} 2\right)$ than $\left(\mathrm{k}_{i d} 1\right)$ indicating that the rate limiting step for $\mathrm{Pb}$ (II) and $\mathrm{Cr}$ (VI) adsorption process is intra- 
particle diffusion. As observed, all the $\mathrm{R}^{2}$ values obtained for IPD for both metal ions were greater than 0.9. This implies that film diffusion (surface phenomenon) also played a dominant role in the adsorption process. As a result, $\mathrm{Pb}$ (II) and $\mathrm{Cr}$ (VI) adsorption onto FS and MFC is considered as a complex process and both intraparticle diffusion and surface adsorption contributed to the rate limiting step Ozdes et al. (2011).

\begin{tabular}{|c|c|c|c|c|}
\hline Metal & $\mathrm{Pb}(\mathrm{II})$ & & $\operatorname{Cr}(\mathrm{VI})$ & \\
\hline Model/ Adsorbent & FC & MFC & FC & MFC \\
\hline $\mathrm{q}_{e} \exp (\mathrm{mg} / \mathrm{g})$ & 16.58 & 20.96 & 12.12 & 18.54 \\
\hline \multicolumn{5}{|c|}{ Pseudo-first-order (PFO) } \\
\hline $\mathrm{q}_{e} \operatorname{cal}(\mathrm{mg} / \mathrm{g})$ & 38.67 & 29.85 & 12.24 & 18.60 \\
\hline $\mathrm{K}_{1}\left(\min ^{-1}\right)$ & 0.18 & 0.14 & 0.09 & 0.10 \\
\hline $\mathrm{R}^{2}$ & 0.8851 & 0.8859 & 0.9737 & 0.9987 \\
\hline \multicolumn{5}{|c|}{ Pseudo-second-order (PSO) } \\
\hline $\mathrm{h}(\mathrm{mg} / \mathrm{g} \min )$ & 1.64 & 2.34 & 0.961 & 0.99 \\
\hline $\mathrm{K}^{2}(\mathrm{~g} / \mathrm{mg} \min )$ & $4.7 \times 10^{-}$ & $6.8 \times 10^{-}$ & $1.7 \times 10^{-}$ & $5.04 \times 10$ \\
\hline $\mathrm{q}_{e} \mathrm{cal}(\mathrm{mg} / \mathrm{g})$ & 16.62 & 21.05 & 26.49 & 32.81 \\
\hline $\mathrm{R}^{2}$ & 0.9999 & 1.0000 & 0.8905 & 0.9025 \\
\hline \multicolumn{5}{|l|}{ Elovich equation } \\
\hline$\alpha(\mathrm{mg} / \mathrm{g} \min )$ & 0.172 & 0.110 & 0.075 & 0.098 \\
\hline$\beta(\mathrm{g} / \mathrm{min})$ & 1.04 & 0.601 & 0.510 & 0.783 \\
\hline $\mathrm{R}^{2}$ & 0.8753 & 0.8845 & 0.8317 & 0.8318 \\
\hline \multicolumn{5}{|c|}{ Intraparticle diffusion (IPD) } \\
\hline $\mathrm{K}_{i d} 1\left(\mathrm{mg} / \mathrm{g} \mathrm{min}^{1 / 2}\right)$ & 0.168 & 1.598 & 1.107 & 1.431 \\
\hline $\mathrm{K}_{i d} 2\left(\mathrm{mg} / \mathrm{g} \mathrm{min}^{1 / 2}\right)$ & 0.157 & 1.282 & 1.023 & 1.310 \\
\hline $\mathrm{C}$ & 0.77 & 6.82 & 3.23 & 6.10 \\
\hline $\mathrm{R}^{2}$ & 0.9647 & 0.9985 & 0.9967 & 0.9976 \\
\hline
\end{tabular}
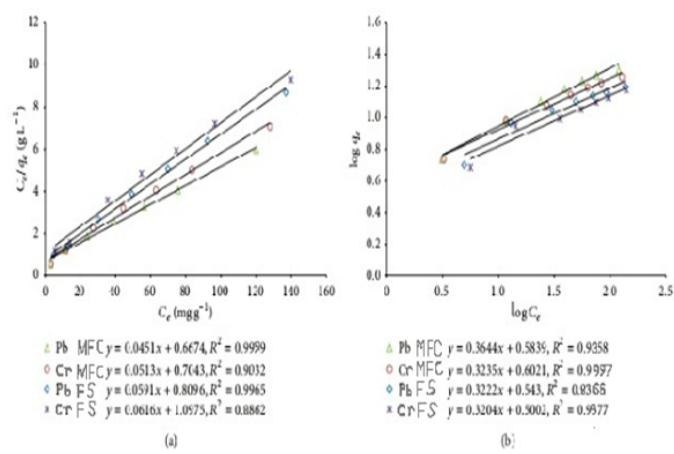

Figure 19 (a) Langmuir isotherm plots (b) Freundlich isotherm plots of adsorption of $\mathrm{Pb}$ (II) and $\mathrm{Cr}$ (VI) onto FS and MFC adsorbents. 

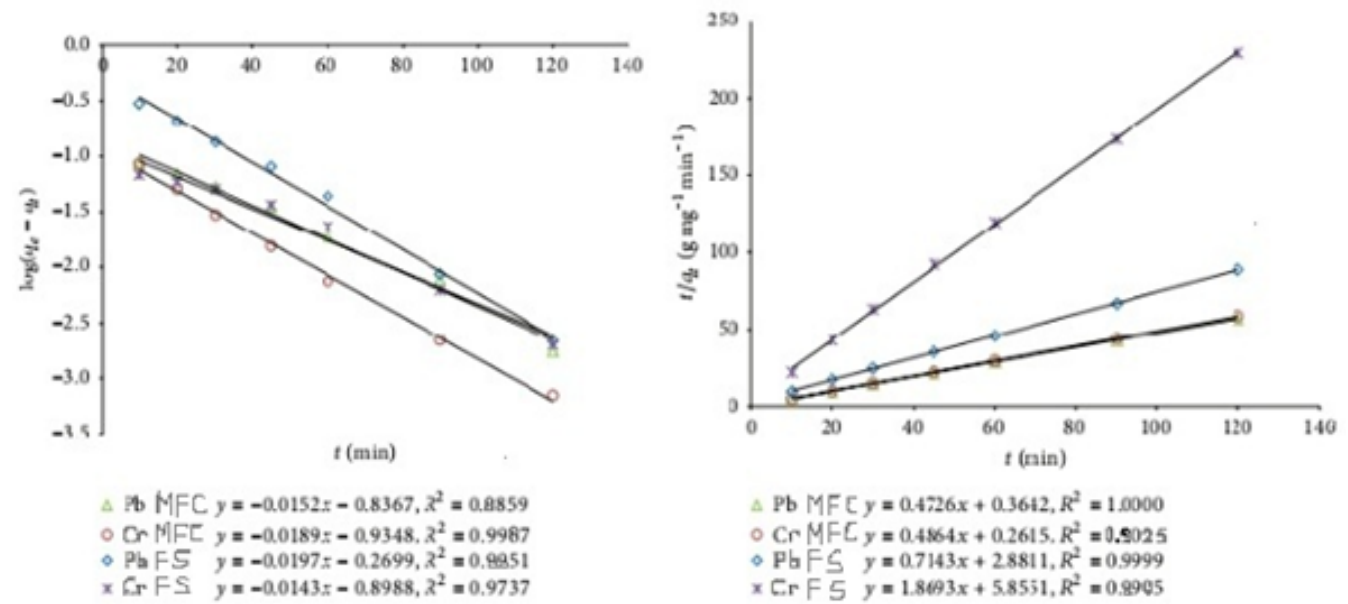

$\triangle \mathrm{Pb} M F C y=0.4226 x+0.3612, R^{2}=1.0000$ - CrMFC $y=0.4864 x+0.2615, R^{2}=0.9025$ OPbFS $y=0.7143 x+28811, R^{2}=0.9999$

$\times$ C. $\mathrm{F} F \mathrm{~F} \quad y=1.8093 x+5.8551, R^{2}=0.8905$

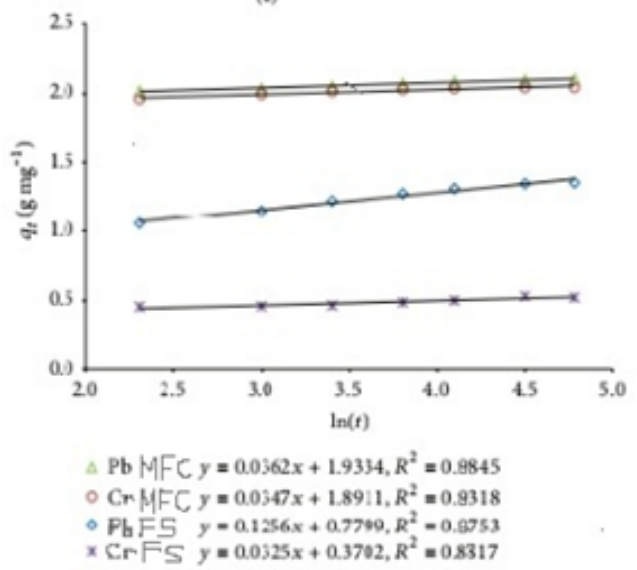

(c)

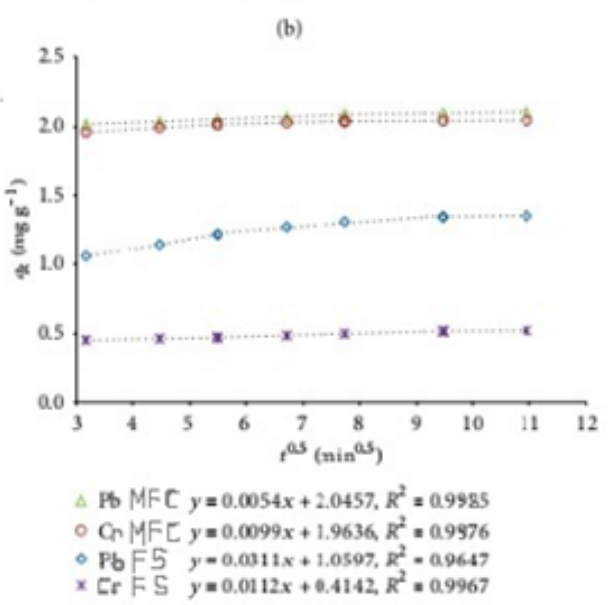

(d)

Figure 20 (a) PFO kinetic plots (b) PSO kinetic plots (c) Elovich plots and (d) Intraparticle diffusion plots of $\mathrm{Pb}(\mathrm{II})$ and $\mathrm{Cr}(\mathrm{VI})$ adsorption onto FS and MFC adsorbents.

\section{CONCLUSION}

From this research it was discovered that the synergestic combination of feldspar with Theobroma cacao pod and calcination has improved its adsorption capacity for lead and chromium ions. Optimum removal of both metal ions was obtained at a $\mathrm{pH}$ of 6.0 for $\mathrm{Pb}$ (II) and $\mathrm{pH} 2.0$ for $\mathrm{Cr}$ (VI) ions, initial metal concentration of 100 $\mathrm{mg} / \mathrm{L}$, adsorbent dosage of $0.5 \mathrm{~g}$ and contact time of $60 \mathrm{~min}$. Results showed that $\mathrm{Pb}$ (II) ions adsorption onto the adsorbents was well fitted to the Langmuir isotherm model, hence chemisorption process while the Cr (VI) ions uptake onto FS and MFC adsorbents followed Freundlich isotherm model, hence suggestive of physisorption process. The results of the kinetic studies showed that the adsorption process for $\mathrm{Pb}$ (II) ions followed pseudo second order model while the rate of adsorption of $\mathrm{Cr}$ (VI) ions onto the FS and MFC adsorbents best fitted pseudo first order model. The Intraparticle diffusion though not the only rate- rate controlling step, played important role in the metal ions adsorption by the adsorbent. However, the modified feldspar 
composite (MFC) showed a faster rate of removal of metal ions in the kinetic analysis than the feldspar adsorbent which is desirable. The results obtained indicated that $\mathrm{Pb}$ (II) and $\mathrm{Cr}$ (VI) ions adsorption process onto the MFC was the complex one involving more than one mechanism. Both homogeneous and heterogeneous active sites were found to exist in the MFC adsorbent. This provides a cheaper alternative means of clay modification rather than the excessively used chemical means which is expensive and noxious to the environment.

\section{REFERENCES}

Adebowale, K. O., Unuabonah, I. E., \& Olu-Owolabi, B. I. (2006). The effect of some operating variables on the adsorption of lead and cadmium ions on kaolinite clay. Journal of Hazardous Materials, 134(1-3), 130-139. Retrieved from https://dx.doi.org/10.1016/ j.jhazmat.2005.10.056 10.1016/j.jhazmat.2005.10.056

Adetokun, A. A., Uba, S., \& Garba, Z. N. (2019). Optimization of adsorption of metal ions from a ternary aqueous solution with activated carbon from Acacia senegal (L.) Willd pods using Central Composite Design. Journal of King Saud University - Science, 31(4), 1452-1462. Retrieved from https://dx.doi.org/10.1016/j.jksus.2018.12.007 10 $.1016 / \mathrm{j} . j \mathrm{ksus} .2018 .12 .007$

Anusa, R., Ravichandran, C., \& Sivakumar, E. K. (2017). Removal of heavy metal ions from industrial waste water by nano-ZnO in presence of electrogenerated Fenton's reagent. International Journal of Chem Tech Research, 10(7), 501-508.

Awala, H., \& Jamal, M. M. (2011). Equilibrium and kinetics study of adsorption of some dyes onto feldspar. Journal of Chemical Technology and Metallurgy, 46(1), 45-52.

CHIBAN, M. (2012). Application of low-cost adsorbents for arsenic removal: A review. Journal of Environmental Chemistry and Ecotoxicology, 4(5), 91-102. Retrieved from https:// dx.doi.org/10.5897/jece11.013 10.5897/jece11.013

Chukwuemeka-Okorie, H. O., Ekemezie, P. N., Akpomie, K. G., \& Olikagu, C. S. (2018). Calcined Corncob-Kaolinite Combo as New Sorbent for Sequestration of Toxic Metal Ions From Polluted Aqua Media and Desorption. Frontiers in Chemistry, 6(6), 1-13. Retrieved from https://dx.doi.org/10.3389/fchem.2018.00273 10.3389/fchem.2018.00273

Dang, V. B. H., Doan, H. D., Dang, V. T., \& Lohi, A. (2009). A Study on Heavy Metal Adsorption Using Shrimp Shell. Journal of Bio-resources Technology, 10(5), 211-223.

Dawood, S. A. (2018).

Demirbas, A. (2004). Adsorption of lead and cadmium ions in aqueous solutions onto modified lignin from alkali glycerol delignication. Journal of Hazardous Material, 10(9), 222226.

Egbu, A. U. (2000). Constraints to Effective Pollution Control and Management in Nigeria. The Environmental Journal, 3(2), 203-205.

Hossain, M. A. (2013). Development of novel biosorbents in removing heavy metals from aqueous solution. Sydney (UTS) Sydney, Australia.

Jimoh, T., Egila, J. N., Dauda, B. E. N., \& Iyaka, Y. A. (2011). Preconcentration and removal of heavy metal ions from aqueous solution using modified charcoal. Journal of Environmental Chemistry and Ecotoxicology, 3(9), 238-243.

Joseph, N., Horsfall, J., Michael, G. U., \& Obuzor. (2015). Preliminary investigation on the Extraction of Heavy metals from produced water using Moringa oleifera Leaves and Seeds as Adsorbents. Research Journal of Chemical Sciences, 5(1), 7-11. 
Karl, M. (2004). Adsorption, Kinetics, and equilibrium studies of $\mathrm{Cr}$ (IV) by hazelnut shell activated carbon. Journal of Adsorption Science and Technology, 22, 51-64.

M., H., ABIA, A. A., \& A.I., S. (2003). Removal of Cu (II) and Zn (II) ions from wastewater by cassava (Manihot esculenta Cranz) waste biomass. African Journal of Biotechnology, 2(10), 360-364. Retrieved from https://dx.doi.org/10.5897/ajb2003.000-1074 $10.5897 /$ ajb2003.000-1074

Ofomaja, A. E., Unuabonah, E. I., \& Oladoja, N. A. (2007). Competitive modeling for the biosorptive removal of copper and lead ions from aqueous solution by Mansonia wood sawdust. Journal of Bioresource Technology, 101(11), 3844-3852.

Ogbu, I. C., Akpomie, K. G., Osunkunle, A. A., \& Eze, S. I. (2019). Sawdust-kaolinite composite as efficient sorbent for heavy metal ions. Bangladesh Journal of Scientific and Industrial Research, 54(1), 99-110. Retrieved from https://dx.doi.org/10.3329/bjsir.v54i1 .40736 10.3329/bjsir.v54i1.40736

Olu-Owolabi, B., Oputu, O. U., Adebowale, K. O., Ogunsolu, O., \& Olujimi, O. O. (2012). Biosorption of $\mathrm{Cd} 2+$ and $\mathrm{Pb} 2+$ ions onto mango stone and cocoa pod waste: Kinetic and equilibrium studies. Scientific Research and Essays, 7(15), 1614-1629.

Olu-Owolabi, B. I., Alabi, A. H., Unuabonah, E. I., Paul, N., \& Diagboya. (2016). Calcined bentonite-biomass composites for removal of aqueous metal ions. Journal of chemical and engineering technology, 4, 1379-1383.

Ozdes, D., Duran, C., \& Senturk, H. B. (2011). Adsorptive removal of Cd(II) and Pb(II) ions from aqueous solutions by using Turkish illitic clay. Journal of Environmental Management, 92(12), 3082-3090. Retrieved from https://dx.doi.org/10.1016/j.jenvman.2011 .07.022 10.1016/j.jenvman.2011.07.022

Rafatullah, M., Sulaiman, O., Hashim, R., \& Ahmad, A. (2010). Adsorption of methylene blue on low-cost adsorbents: A review. Journal of Hazardous Materials, 177(1-3), 70-80. Retrieved from https://dx.doi.org/10.1016/j.jhazmat.2009.12.047 10.1016/j.jhazmat 2009.12.047

Saeed, A., Iqbal, M., \& Akhtar, M. W. (2005). Removal and recovery of lead(II) from single and multimetal ( $\mathrm{Cd}, \mathrm{Cu}, \mathrm{Ni}, \mathrm{Zn}$ ) solutions by crop milling waste (black gram husk). Journal of Hazardous Materials, 117(1), 65-73. Retrieved from https://dx.doi.org/10.1016/j .jhazmat.2004.09.008 10.1016/j.jhazmat.2004.09.008

Salih, A. M. (2017). The purification of industrial wastewater to remove heavy metals and investigation into the use of zeolite as a remediation tool. A thesis submitted in partial fulfilment of the requirements of the University of Wolverhampton for the degree of Doctor of Philosophy, 31-33.

Sanusi, K. A., \& Umar, B. A. (2016). Evaluation of the Application of Carica papaya Seed Modified Feldspar Clay for Adsorption of $\mathrm{Pb}+2$ and $\mathrm{Cu}+2$ in Aqueous Media: Equilibrium and Thermodynamic studies. Journal of Environmental \& Analytical Toxicology, 06(02), 2-09. Retrieved from https://dx.doi.org/10.4172/2161-0525.1000351 10.4172/2161-0525.1000351

Singh, R., \& Bhateria, R. (2020). Optimization and Experimental Design of the Pb2+ Adsorption Process on a Nano-Fe304-Based Adsorbent Using the Response Surface Methodology. ACS Omega, 5(43), 28305-28318. Retrieved from https://dx.doi.org/10.1021/ acsomega.0c04284 10.1021/acsomega.0c04284

Unuabonah, E. I., Günter, C., Weber, J., Lubahn, S., \& Taubert, A. (2013). Hybrid Clay: A New Highly Efficient Adsorbent for Water Treatment. ACS Sustainable Chemistry \& Engineering, 1(8), 966-973. Retrieved from https://dx.doi.org/10.1021/sc400051y 10.1021/ sc400051y 
Unuabonah, E. I., Olu-Owolabi, B. I., Adebowale, K. O., \& Ofomaja, A. E. (2007). Adsorption of lead and cadmium ions from aqueous solutions by tripolyphosphate-impregnated Kaolinite clay. Colloids and Surfaces A: Physicochemical and Engineering Aspects, 292(23), 202-211. Retrieved from https://dx.doi.org/10.1016/j.colsurfa.2006.06.024 10 .1016/j.colsurfa.2006.06.024

Who. (2000). Guidelines for drinking water quality by World Health Organization. Geneva, Switzerland.

Yazdani, M., Bahrami, H., \& Arami, M. (2014). Preparation and Characterization of Chitosan/Feldspar Biohybrid as an Adsorbent: Optimization of Adsorption Process via Response Surface Modeling. The Scientific World Journal, 2014(14), 1-13. Retrieved from https://dx.doi.org/10.1155/2014/370260 10.1155/2014/370260 